\title{
А. Донабедян
}

INALCO / SeDyL, Париж

\section{СЕМАНТИКА АОРИСТА В СОВРЕМЕННОМ АРМЯНСКОМ ЯЗЫКЕ: ИНВАРИАНТНЫЕ ЗНАЧЕНИЯ И ИХ КОНТЕКСТНЫЕ РЕАЛИЗАЦИИ ${ }^{1}$}

\section{1. Введение}

Сравнение отдельных грамматических показателей демонстрирует, что во многих языках отчетливо выделяется глагольное время, которое можно описать как аорист. Термин аорист, восходящий к греческой традиции, широко используется применительно ко многим индоевропейским языкам. Аорист реконструируется для протоиндоевропейского и имеет давнюю традицию изучения, привлекая и сегодня большой интерес лингвистов. Вместе с тем, начиная с Аристотеля и вплоть до современного лингвиста А. Кюльоли [Culioli 1980] ${ }^{2}$, авторы обращают внимание на тот факт, что для выделения аориста как особой грамматической категории с особыми видовыми и залоговыми характеристиками, собственно говоря, не требуется особой глагольной формы. Это позволяет распространить концепцию аориста на языки, не относящиеся к индоевропейской семье, такие, например, как турецкий, где понятие аориста прочно вошло в грамматическую традицию, или на язык волоф (атлантическая семья), для которого Ст. Робер [Robert 1996] также выделяет аорист. Однако в случае турецкого или волоф видо-временная семантика аориста явно отклоняется от семантики перфектива прошедшего

1 Эта статья является русской версией статьи [Donabédian 2016].

${ }^{2}$ В ходе работы с гранками этой книги мы получили трагическое известие о кончине Антуана Кюльоли, последовавшей 10 февраля 2018 года. Лидер одной из самых заметных школ во французском языкознании последних десятилетий, Антуан Кюльоли оказал прямое влияние на многих из нас, в том числе и в осмыслении вопросов, которые рассматриваются в этом томе. Скорбя о его уходе, мы отдаем здесь дань уважения самобытному лингвисту и яркому мыслителю. 
времени, которую индоевропеисты и некоторые типологи, начиная с Э. Даля [Dahl 1985] приписывают аористу. Общим для аориста во всех указанных языках является следующее:

1) С точки зрения формы - минимальная морфология, вплоть до полного отсутствия морфемного маркирования в глагольной форме (так в персидском kard ‘делать' [Lazard 1957]), но нигде не встречаются перифрастические формы. Например, в хинди аорист и контрфактив являются единственными безаффиксными индикативными формами глагола [Montaut 2006а]. Примечательно, что в более ранней грамматике волоф парадигма, описанная Ст. Роберт как аорист [Robert 1996], определялась как «нулевой вид» (aspect zéro) [Sauvageot 1965: 102].

2) Отсутствие локализации относительно момента речи [Culioli 1980] $]^{3}$ или речевой ситуации [Robert 1996]. Как будет показано ниже, временная локализация ситуации в аористических высказываниях осуществляется не через глагол, а через контекст (нарративная структура, причастия, и т д.). Высказывание может также остаться нелокализованным во времени (гномическое, гипотетическое и другие сходные значения). Из этого следует более гибкое временное значение по сравнению с прочими формами прошедшего времени, поскольку аорист способен

${ }^{3}$ «L'aoristique est défini par l'opération de repérage $\operatorname{Sit}_{0}\left(S_{n}, T_{n}\right) \omega$ $\mathrm{Sit}_{\mathrm{m}}, \mathrm{T}_{\mathrm{m}}$ où $\mathrm{Sit}_{\mathrm{m}}$ (le repère) et $\mathrm{Sit}_{\mathrm{n}}$ (le repéré) sont deux occurrences distinctes de Sit, quel que soit, pour le problème considéré, le statut de $\mathrm{Sit}_{\mathrm{m}}, \mathrm{Sit}_{\mathrm{n}}$ » («Аористичное определяется через операцию локализации $\operatorname{Sit}_{0}\left(\mathrm{~S}_{\mathrm{n}}, \mathrm{T}_{\mathrm{n}}\right) \omega$ $\mathrm{Sit}_{\mathrm{m}}, \mathrm{T}_{\mathrm{m}}$, где $\mathrm{Sit}_{\mathrm{m}}$ (локализатор) и $\mathrm{Sit}_{\mathrm{n}}$ (локализуемое) являются двумя отдельными представителями Sit, каким бы ни был применительно к рассматриваемой проблеме статус $\mathrm{Sit}_{\mathrm{m}}$ и $\mathrm{Sit}_{\mathrm{n}}$ » [Culioli 1980: 191]. «La relation $\omega$ est la relation de rupture» "ni identique ni différent”» («Отношение $\omega$ является отношением разделения "ни идентичным, ни отличным"» [Culioli 1980: 183]. «L'aoristique est une catégorie dont les marqueurs peuvent être le passé simple, l'imparfait, le passé composé, le présent, le futur, pour s'en tenir à ces exemples» («Аористичное - это категория, показателем которой может быть простое прошедшее, имперфект, прошедшее сложное, настоящее, будущее и др.» [Culioli 1980: 191]. См. также [Vogüé 1995]. 
совмещать на первый взгляд несовместимые значения, например, прошедшего и будущего времен.

В ряде языков, в частности, в индоевропейских (таких как персидский, болгарский, греческий и даже французский, если следовать за Э. Бенвинистом в его понимании Passé simple) глагольное время, понимаемое как аорист, совмещает так называемое претеритное значение (в смысле неперифрастического перфектива прошедшего времени, что соответсвует определению аориста у Э. Даля) и аористическое значение (неопределенное в отношении категории времени). Именно такая ситуация наблюдается и в современном армянском языке.

В данной статье мы рассмотрим в общих чертах место аориста в системе модальных и видо-временных форм современного армянского языка. Мы будем опираться как на данные этимологии и морфологии, так и на грамматические варианты употребления форм аориста в синхронии. Мы также попытаемся выделить основные параметры таких вариантов. Употребление аориста в армянском языке будет сопоставлено с другими современными языками, с целью выявления общих и специфических характеристик этой категории. На основе систематического сопоставления восточно- и западноармянского аориста будут рассмотрены проблемы языковой вариативности и языковых контактов.

Используемый нами подход сложился под влиянием теории «лингвистики высказывания» А. Кюльоли (ср., например, [Culioli 1990]). Как представляется, теория Кюльоли особенно хорошо подходит для осмысления того, как функционирует аорист. Помещая высказывание в центр грамматического анализа, эта теория позволяет проследить, как один и тот же контекст может быть выражен различными грамматическими формами, в зависимости от ситуации высказывания и субъективной позиции говорящего. При таком подходе грамматические маркеры рассматриваются как языковые операторы, а не как маркеры кодирования внеязыковой действительности. Операторы определяются скорее через их собственную (инвариантную) функцию, а не через правила их употребления, которые иногда можно попытаться выделить, но которые неизбежно имеют много исключений, не всегда поддающихся объяснению. 


\section{2. О чем говорит место аориста в глагольной системе армянского языка?}

Даже при поверхностном знакомстве с глагольной системой армянского языка, будь то древнеармянский, восточный или западный современный армянский ${ }^{4}$, становится очевидно, что аорист занимает специфическую и ассиметричную позицию по каждому из параметров морфологической структуры. Продемонстрируем это на примере глагола иtem 'есть', в стандартных вариантах обоих современных языков.

${ }^{4}$ Эти два нормативных варианта современного армянского языка сложились в XIX веке на основе богатых литературных традиций. Восточноармянский (далее ВА) является официальным языком Республики Армения, а также языком армянской общины в Иране. Западноармянский (далее 3А), на котором говорили и на котором велось обучение в Османской империи, является языком западной диаспоры, и главным языком общения и преподавания в общинах Среднего и Ближнего Востока (особенно в Сирии и в Ливане). Между ЗА и ВА прослеживаются различия в лексике, фонологии, морфологии и синтаксисе. В данной статье учитываются оба варианта языка, поскольку у них не так много различий в выражении аориста, на которых мы остановимся ниже. По умолчанию, наши выводы касаются обоих современных вариантов языка. При отсутствии специальных ссылок, все примеры приводятся из «Национального корпуса восточноармянского языка» (eanc.net). Примеры из западноармянского языка отмечаются отдельно, и по умолчанию являются результатом элицитации. Западноармянский не принял орфографическую реформу, принятую в советской Армении. Транскрипция, используемая ниже, базируется на принятой в арменоведении «научной транслитерации», принятой в работах Г. Гюбшмана, А. Мейе и Э. Бенвениста, но не отражает орфографических особенностей, сложившихся в западноармянском. Учитывая консонантные чередования, имевшие место в западноармянском и не отраженные в орфографии, понятно, что транслитерация существенно отошла от фонетики языка как в словах армянского происхождения, так и в иностранных словах, записанных по-армянски. Наш выбор обусловлен желанием сделать более наглядными рассматриваемые параллели в ЗА и ВА.

${ }^{5}$ Перфектная и имперфектная основы обычно маркируются суффиксом -Ø-/-с'-, но могут также бытъ супплетивные пары, как в случае utem (чередование корней $u t-/ k e r$-). 
Семантика аориста в современном армянском языке

Таблица 1. Обзор западноармянской глагольной системы

\begin{tabular}{|c|c|c|c|}
\hline Основа & Время & Утверд. форма & Отриц. форма \\
\hline \multirow{4}{*}{$\begin{array}{l}\text { Импер- } \\
\text { фектив }\end{array}$} & императив ед.ч. & ker! & mi! uter \\
\hline & $\begin{array}{l}\text { субъюнктив през. } \\
\text { субъюнктив имперф. }\end{array}$ & \begin{tabular}{|l|} 
ute- $m$ \\
ute- $i$ \\
\end{tabular} & \begin{tabular}{|l|}
$\check{c}^{6}-$ ute-m \\
$\check{c}^{\prime}-$ ute- $i$ \\
\end{tabular} \\
\hline & $\begin{array}{l}\text { презенс } \\
\text { имперфект }\end{array}$ & \begin{tabular}{|l|}
$k^{\prime}-u t e-m$ \\
$k^{\prime}-u t \bar{e}-i$
\end{tabular} & $\begin{array}{l}\check{c}^{\prime}-\text {-em ut-er } \\
\check{c}^{c}-e i \text { ei }-e r\end{array}$ \\
\hline & $\begin{array}{l}\text { будущее } \\
\text { будущее в прош. }\end{array}$ & $\begin{array}{l}\text { piti ute-m } \\
\text { piti ute- } i\end{array}$ & $\begin{array}{l}\text { piti } \check{c}^{c} \text {-ute-m } \\
\text { piti } c^{c} \text {-ute-i }\end{array}$ \\
\hline \multirow{3}{*}{ Перфектив } & аорист & ker-a & $\check{c}^{6}-$ ker-a \\
\hline & $\begin{array}{l}\text { перфект } 1 \\
\text { плюсквамперф. } 1\end{array}$ & $\begin{array}{l}\text { ker-ac em } \\
\text { ker-ac èi }\end{array}$ & $\begin{array}{l}\check{c} ' \text {-em kerac } \\
\check{c}^{\prime} \text {-ei kerac }\end{array}$ \\
\hline & $\begin{array}{l}\text { перфект } 2 \\
\text { плюсквамперф. } 2\end{array}$ & $\begin{array}{l}\text { ker-er em } \\
\text { ker-er èi }\end{array}$ & $\begin{array}{l}\check{c} \text { '-em kerer } \\
\check{c}^{\prime} \text {-ei kerer }\end{array}$ \\
\hline
\end{tabular}

Таблица 2. Обзор восточноармянской глагольной системы

\begin{tabular}{|c|c|c|c|}
\hline Основа & Время & Утверд. форма & Отриц. форма \\
\hline \multirow{6}{*}{$\begin{array}{l}\text { Импер- } \\
\text { фектив }\end{array}$} & императив ед.ч. & ker! & mi! ker \\
\hline & $\begin{array}{l}\text { субъюнктив през. } \\
\text { субъюнктив имперф. }\end{array}$ & $\begin{array}{l}\text { ute- } m \\
\text { ute- } i\end{array}$ & $\begin{array}{l}\check{c}^{c}-\text { ute- } m \\
\check{c}^{c}-\text { ute- } i\end{array}$ \\
\hline & $\begin{array}{l}\text { презенс } \\
\text { имперфект }\end{array}$ & $\begin{array}{l}\text { utum em } \\
\text { utum ei }\end{array}$ & $\begin{array}{l}\check{c}^{\prime}-\text { em utum } \\
\check{c}^{\prime}-\text { ei utum }\end{array}$ \\
\hline & $\begin{array}{l}\text { будущее } 1 \\
\text { будущее в прош. } 1\end{array}$ & $\begin{array}{l}\text { utelu em } \\
\text { utelu ei }\end{array}$ & $\begin{array}{l}\text { utelu } \check{c}^{\prime}-\text {-em } \\
\text { utelu } \check{c}^{`}-e i\end{array}$ \\
\hline & $\begin{array}{l}\text { будущее } 2 \\
\text { будущее в прош. } 2\end{array}$ & \begin{tabular}{|l|} 
piti ute-m \\
piti ute-i
\end{tabular} & $\begin{array}{l}\check{c}^{c} \text {-piti ute-m } \\
\check{c}^{c} \text {-piti ute-i }\end{array}$ \\
\hline & $\begin{array}{l}\text { будущее } 3 \\
\text { кондиционалис }\end{array}$ & \begin{tabular}{|l|}
$k$-ute-m \\
$k$-ute-i \\
\end{tabular} & \begin{tabular}{|l|}
$\check{c}^{6}-$ em uti \\
$\check{c}^{c}-$-ei uti \\
\end{tabular} \\
\hline \multirow[b]{2}{*}{ Перфектив } & аорист & ker-a & $\check{c}^{\prime}-$ ker-a \\
\hline & $\begin{array}{l}\text { перфект } \\
\text { плюсквамперфект }\end{array}$ & $\begin{array}{l}\text { kerel em } \\
\text { kerel ei }\end{array}$ & $\begin{array}{l}\check{c} \text { c'em kerel } \\
\text { c’ei kerel }\end{array}$ \\
\hline
\end{tabular}

Таблицы 1-2 показывают, что система модальных и видовременных форм в современном армянском языке характеризуется определенным набором морфологических оппозиций:

1) В глагольной основе маркируется противопоставление по виду: основа имперфектива (называемая также основой настоящего времени) противопоставляется основе перфектива (называемой также основой аориста). Следует отметить, что от основы имперфектива образуется широкий диапазон наклонений (сослага- 
тельное, изъявительное, условное и повелительное наклонение для правильных бессуфиксных глаголов ${ }^{6}$ ), тогда как основа перфектива употребляется только для изъявительного наклонения.

2) Флексия также маркирует темпоральную оппозицию между прошедшим и настоящим временем. Все формы, за исключением аориста и императива, структурированы в рамках бинарной оппозиции настоящее/прошедшее, как это видно из таблиц 1-2, где большинство ячеек содержит противопоставленные таким образом парные формы. В. А. Плунгян [2006] обозначает это явление термином «темпоральная подвижность». Аорист является единственным флективным временем, не обладающим этой характеристикой.

Подобные типы противопоставлений хорошо известны в индоевропейских языках и представлены в древнеармянском. Третий же тип морфологической оппозиции (см. ниже) развился в глагольной системе уже в современном языке.

3) Способ образования словоформы, синтетический (основа + флексия) или аналитический (частица ${ }^{7}+$ флективная форма или вспомогательный глагол + нефинитная форма), связывается с маркированием модальности. Частица маркирует ассертивный статус (актуализация в терминах Кюльоли), в то время как вспомогательный глагол маркирует связь с ситуацией высказывания. Тот факт, что эти два типа маркирования могут не совпадать в утвердительных и отрицательных формах одного и того же

${ }^{6}$ Императив единственного числа образуется в зависимости от класса глагола от основы настоящего времени (правильные переходные глаголы) или от основы аориста (суффиксальные инхоативные и каузативные глаголы, а также неправильные первичные глаголы, такие как ker 'ешь!', образующиеся непосредственно от формы аориста). Образование формы императива существенно различается в ВА и ЗА.

Мы используем термин «частица» для обозначения всех превербальных видо-временных маркеров, будь то префиксы или отдельные слова. Относительно $k($ ) отметим, что эта морфема выступает как слово (проклитика) в ЗА и как префикс в ВА. При том, что грамматикализация $k($ ) происходила в двух языках, по-видимому, в разные периоды, различия, связанные с нормой их написания, не отражают их грамматическую природу. 
времени (ср. настоящее время в ЗА, Таблица 1), показывает, что они являются двумя способами выражения одной операции.

Так, в Таблицах 1 и 2 мы видим, что времена могут быть ранжированы по признаку их морфологического «веса» от наиболее «легкого» к наиболее «тяжелому» ${ }^{8}$ :

Таблица 3. Ранжирование глагольных форм современного армянского по морфологическому «весу»

\begin{tabular}{|c|c|c|c|c|}
\hline $\begin{array}{l}\tilde{0} \\
\stackrel{0}{0} \\
\stackrel{\mathbb{M}}{0} \\
0\end{array}$ & 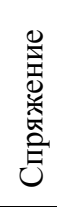 & 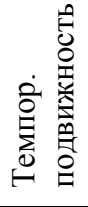 & 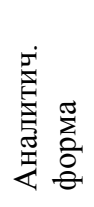 & \\
\hline$x$ & & & & императив единственного лица \\
\hline$x$ & $x$ & & & аорист \\
\hline$x$ & $x$ & $x$ & & субъюнктрив настоящего/прошедшего \\
\hline$x$ & $x$ & $x$ & $x$ & наст./имперф. \\
\hline$x$ & $x$ & $x$ & $x$ & буд./буд. в прош. или условное \\
\hline$x$ & $x$ & $x$ & $x$ & $\begin{array}{l}\text { перф./ плюсквамперф. и формы с двойным } \\
\text { вспомогательным глаголом }\end{array}$ \\
\hline$x$ & $x$ & $x$ & $x$ & перф.2/плюсквамперф.2 (эвиденциальный) \\
\hline$x$ & $x$ & $x$ & $x$ & $\begin{array}{l}\text { полу-грамматикализированные перифрас- } \\
\text { тические формы (и все отрицательные фор- } \\
\text { мы, прохибитив) }\end{array}$ \\
\hline
\end{tabular}

Приведенная в Таблице 3 иерархия форм показывает, что аорист, как и ожидается в соответствии с кросслингвистическими особенностями этой категории, является в армянском одной их самых минимальных морфологических глагольных форм. По своим модальным характеристикам она отчетливо противопоставлена соседним формам в иерархии, - парадокс, который обна-

${ }^{8}$ Темпоральные парадигмы ВА и ЗА совпадают лишь частично. Даже при совпадения на уровне категорий, стратегии маркирования форм могут различаться. Так, в изъявительном наклонении утвердительные формы оформляются с помощью вспомогательного глагола в ВА и частицы в ЗА. Это не противоречит общим особенностям распределения морфологических признаков в Таблице 3. 
руживается и в других языках (например, в хинди аорист и контрфактив являются единственными синтетическими формами). Аорист, оставаясь ассертивным и актуализированным временем (иначе говоря, временем индикатива), имеет тот же «вес», что и неиндикативный субъюнктив. Впрочем, аорист отличается от субъюнктива ${ }^{9}$, как и от всех прочих флективных форм за исключением императива, тем, что он не входит в бинарную оппозицию настоящее/прошедшее.

Из Таблиц 1, 2 и 3 становится ясно, что аорист занимает особое положение в глагольной системе современного армянского языка, что уже отмечалось в некоторых исследованиях, последними из которых являются [Плунгян 2006] и [Giorgi, Harutyunian 2011]. В.А. Плунгян подчеркивает тот факт, что аорист существует вне системы форм прошедшего, в то время как А. Джиорджи и С. Арутюнян идут еще дальше и предлагают рассматривать аорист как перфектив без темпорального маркирования, принимая во внимание тот факт, что в современном армянском аорист может выражать также и будущее время.

С учетом изложенного выделяются два основых вопроса, касающихся статуса аориста в современном армянском:

1) Учитывая, что аорист не имеет маркера актуализации (ни вспомогательного глагола, ни частицы), является ли он временем индикатива ${ }^{10}$ ?

2) Учитывая, что аорист не участвует в темпоральной оппозиции, относится ли он к прошедшему времени?

${ }^{9}$ Параметр темпоральной подвижности имеет особый статус по сравнению с другими параметрами. Он показывает, каким образом синтетические формы субъюнктива, имея тот же морфологический «вес», что и аорист, оказываются ниже его во флективной иерархии, поскольку только аорист обладает темпоральной подвижностью.

${ }^{10}$ В. А. Плунгян, рассматривая только ВА, связывает модальность с темпоральной подвижностью (в грамматике ВА, то, что мы называем будущее 3 , определяется как условное, а наше будущее 2 как дебитив). Действительно, из того факта, что настоящее время также выражается в ВА с помощью вспомогательного глагола, можно было бы сделать вывод о том, что аналитические формы характеризуют времена индикатива, а синтетические формы являются неиндикативными. 
В конечном счете, эти вопросы имеют отношение к тому, как мы понимаем различие между аористом и претеритом. В армянской грамматической традиции аорист определяется как anc 'eal katareal, “прошедшее совершенное” («past perfect»), что соответствует именно такому пониманию претерита, которое было дано выше.

Обратимся к анализу аориста. А. Джиорджи и С. Арутюнян [Giorgi, Harutyunian 2011: 98], опираясь на диахронию армянского аориста, справедливо отмечают, что основа армянского аориста, которая начиная с древнеармянского периода маркируется морфемой -c'-, передает скорее видовое чем временное значение. Однако они не учитывают окончаний аориста, которые, вне всякого сомнения, являются показателями прошедшего времени, хотя аорист и не входит в бинарную темпоральную оппозицию. При этом невозможно отрицать, что аорист является формой перфектива прошедшего времени. Это очевидно как в отношении регулярных глагольных классов (например, grel 'писать'), так и в отношении нерегулярных классов с так называемым спряжением аориста второго типа (например, amusnanal 'жениться') ${ }^{11}$.

Таблица 4. Аорист и показатели времени

\begin{tabular}{|c|c|c|c|}
\hline & През. & Имперф. & Aop. \\
\hline $1 \mathrm{sg}$. & gre-m & gre-i & grec $^{\prime}-\boldsymbol{i}$ \\
\hline $2 \mathrm{sg}$. & gre-s & gre-ir & grec '-ir \\
\hline $3 \mathrm{sg}$. & gre- $\varnothing$ & gre-r & grec $-\varnothing$ \\
\hline $1 \mathrm{pl}$. & gre-nk' & gre-ink' & grec'-ink' \\
\hline $2 \mathrm{pl}$. & gre-k' & gre-ik' & $\operatorname{grec}^{\prime}-i k^{\prime}$ \\
\hline $3 \mathrm{pl}$. & gre-n & gre-in & grec $^{\prime}-$ in \\
\hline
\end{tabular}

\begin{tabular}{|c|c|c|c|}
\hline & През. & Имперф. & Aop. \\
\hline $1 \mathrm{sg}$. & amusnana-m & amusnanay-i & amusnac'-a \\
\hline $2 \mathrm{sg}$. & amusnana-s & amusnanay-ir & amusnac'-ar \\
\hline 3 sg. & amusnana- $\varnothing$ & amusnana-r & amusnac'-av \\
\hline $1 \mathrm{pl}$. & amusnana-nk & amusnanay-ink & amusnac'-ank' \\
\hline $2 \mathrm{pl}$. & amusnana-k' & amusnanay-ik' & amusnac $^{\prime}-\boldsymbol{a} k^{\prime}$ \\
\hline $3 \mathrm{pl}$. & amusnana- $n$ & amusnanay-in & amusnac'-an \\
\hline
\end{tabular}

${ }^{11}$ Приведенные здесь глаголы распределяются по флективным классам одинаково в ВА и в ЗА, хотя инвентарь глаголов не совпадает. 
В регулярных глагольных классах типа 1 (grel), окончание $-i$, совпадающее в аористе и имперфекте, маркирует прошедшее время. Что касается типа amusnanal, совпадение -r в 2 sg. имперфекта и аориста показывает принципальное сходство между типами 1 и 2 несмотря на различные гласные (-ir/-ar).

Таким образом, с точки зрения морфологии мы можем охарактеризовать аорист в армянском как:

a) перфектив прошедшего времени (флексия прошедшего времени, присоединяемая к основе перфектива);

b) синтетический тип по способу образования словоформы;

c) не участвующий в бинарной оппозиции настоящее/ прошедшее.

На семантическом уровне, интерпретация аориста как перфектива прошедшего времени подтверждается большим количеством примеров с претеритальным значением, хотя оно и не исчерпывает всех употреблений аориста ни в армянских грамматиках, ни в корпусе. По всей видимости, для того, чтобы лучше понять природу аориста, необходимо учитывать и его формальные характеристики. Так, например, учитывая критерий темпоральной подвижности, В.А. Плунгян ставит под сомнение связи аориста с индикативом и подчеркивает важность параметра модальности.

Согласимся с Плунгяном в том, что модальность является ключом к пониманию аориста. Следует, однако, отметить, что его выводы ослабляются тем, что анализ во многом основывается на изолированном рассмотрении времен индикатива вне их связей с глагольной системой в целом. Если же мы будем рассматривать аорист как часть модального континиуума, не относя его априорно к индикативу, то выводы могут быть другими. Моя гипотеза состоит именно в том, что наклонение не является бинарным признаком, структурирующим армянскую глагольную систему, которая организована скорее по принципу градуальной оппозиции, коррелизующей с иерархией морфологических «весов», приведенной в Таблице 3. В таком случае, вопрос, поднятый В.А. Плунгяном, можно переформулировать следующим образом: занимая соседнее положение с императивом и субъюнктивом в иерархии по морфологическому «весу», относится ли аорист к индикативу? 
Историческое развитие стратегий маркирования индикатива в глагольной системе армянского языка, связаное с хорошо известными в типологии процессами ${ }^{12}$, говорит в пользу именно градуального решения, в связи с чем термин «индикатив», возможно, следует заменить на термин, характеризующий маркирование актуализации. Такой подход нуждается в параметре, связанном с модальностью и определяющем тип высказывания.

В восходящей к Э. Бенвенисту лингвистической традиции, которой следует и Кюльоли, параметр «тип высказывания» находится в самом центре грамматического анализа, а не ограничивается отдельным языковым уровнем, например, прагматикой. Некоторые особенности теоретического подхода Кюльоли представляются исключительно полезными для интересующего нас вопроса. Первая из таких особенностей состоит в хорошо известном противопоставлении текста (нарративный регистр) и дискурса (дискурсивный регистр), необходимость различения которых была сформулирована Бенвенистом ${ }^{13}$. Не менее важны базовые понятия теории ассертивности Кюльоли, интепретирующей речевую ситуацию $\left(\mathrm{Sit}_{0}\right)$ как совмещение двух координат: говорящий $\mathrm{S}_{0}$ и момент речи $\mathrm{T}_{0}$. Вслед за Кюльоли, мы также определяем ассертивный акт следующим образом: высказывание Солнце светит, в действительности, содержит в себе три утверждения, (1) Я говорю, (2) солнще светит, (3) это истинно. (1) представляет координаты высказывания, (2) содержание пропозиции (как его определяет Серль), (3) суждение об истинности, гарантом которой является говорящий.

12 Д. Коэн [Cohen 1985] описывает процесс, который в диахронии семитских языков приводит к переходу показателя презенса в показатель субъюнктива в результате создания новой формы презенса с более отчетливым маркированием актуализации. Сходным образом древнеармянские морфологически тяжелые формы субъюнктива были заменены к новоармянскому периоду формами, выражавшими в древнеармянском презенс, в то время как для выражения презенса в новоармянском возникли перифрастические формы.

${ }^{13}$ О различении понятий «истории» (histoire), изначально предложенного Бенвенистом, и «рассказа» (récit), который используется в данной работе, см. [Vogüé 1989]. 
Действительно, следуя логике Д. Коэна [Cohen 1985], удивительная диахроническая стабильность армянского аориста, на которую неоднократно обращали внимание лингвисты (например, [Markarian 2004: 435]), может указывать на его особую связь с актуализацией высказывания. Можно предположить, что диахроническая стабильность, отличающая аорист от других индикативных времен, вызвана тем, что его ассертивная функция теснейшим образом связана с нарративным регистром. Наоборот, устойчивые стратегии маркирования актуализации в презенсе связаны с перифрастическими формами, которые являются результатом грамматикализации показателей дискурсивных значений ${ }^{14}$.

С этих позиций, ставя задачу прояснить описание армянского аориста в свете его формальных и семантических характеристик, мы рассмотрим употребления аориста в современном армянском языке по данным грамматик и корпуса (см. сноску 4). Мы попытаемся уточнить характеристики каждой разновидности его употребления и соотнести их со специфическими свойствами аориста в глагольной системе армянского языка. Вначале мы рассмотрим более однородные употребления, связанные с нарративным регистром, а затем перейдем к рассмотрению гетерогенных употреблений, связанных с дискурсивным регистром.

\section{3. Значения аориста в современном армянском}

В [Donabédian 1998] были формулированы характеристики 3А аориста в его отношении к высказыванию и выделены три актуальных для аориста различительных признака: событийность, компактность и отсутствие локализации относительно речевой

${ }^{14}$ Именно это произошло в армянском с частицей $k$ - $/ k \partial$, которая подверглась грамматикализации в среднеармянский период (по историческим причинам, эта стадия языка доступна только в западном ареале), восходит к дефективному глаголу $k a$ 'держаться, стоять', который (1) изначально употреблялся в сочетании со стативными глаголами $k a u$ mna 'стоит и остается тут', (2) позже - со всеми типами глаголов, затем (3) он грамматикализуется в форме $k u$ и, наконец, (4) его алломорф $k$-/kә расширяет значение и становится в 3А маркером индикатива настоящего времени (актуализированного), по контрасту с субъюнктивом настоящего времени. 
ситуации. Такая интерпретация соответствует подходу к аористу, развиваемому в рамках идей Кюльоли на материале самых разных языков ([Guentchéva 1990; Vassilaki, Tsamadou 1995; Montaut 2006a, 2006b]).

В данном разделе будет показано, как эти три свойства проявляются в употреблениях аориста в армянском, и почему учет именно этих свойств лучше подходит для объяснения очень противоречивой природы аориста, чем учет характеристик, выделяемых в грамматиках, будь то традиционные армянские грамматики ${ }^{15}$ или интерпретации, основанные на различных типологических подходах, как например, грамматика Ж. Дум-Трагут [Dum-Tragut 2009].

Как будет показано ниже, эти три свойства позволяют описать специфику аориста без необходимости выделять многочисленные исключения, связанные с ограничениями в употреблении аориста, которые фиксируются в грамматиках (семантические свойства процесса, несовместимость аориста с некоторыми глаголами, контекстами, etc.).

Возможно, именно стремление учесть многочисленные исключения побудило Ю.С. Маслова [Маслов 1981: 248] использовать исключительно негативные формулировки для описания аориста в болгарском: «Аорист констатирует прошедшее (или мыслимое как прошедшее) действие без рассмотрения этого действия в самом процессе его протекания и без учета его отношения к положению дел в момент речи». Такое определение вызвало критические замечания Ф. Сейлера, приводимые 3. Генчевой [Guentchéva 1990: 94]. Сильная сторона такой формулировки состоит в том, что автор, не являясь последователем теории актов высказывания, тем не менее, помещает в центр определения позицию говорящего и тем самым избегает исключений, неизбежных при других чисто референциальных формулировках.

Рассматривая три указанных свойства на примерах из армянского языка, мы попытаемся показать, что употребление

${ }^{15}$ От грамматики Абегяна начала $20-\mathrm{x}$ годов до грамматики Маркаряна [Markarian 2004]. 
аориста в армянском скорее предполагает выбор говорящего, нежели указывает на ограничения, налагаемые контекстом высказывания (тип события/действия, длительность действия и т.д.) или лингвистическим контекстом (сочетаемость с некоторыми наречиями, связь с другими действиями, еtс.). Влияние контекста проявляется лишь как тенденция, а не является правилом.

Ниже мы проиллюстрируем важное различие между употреблениями аориста, с одной стороны, в нарративном регистре (récit), который характеризуется временной отнесенностью сообщаемого факта к прошлому и логическим отношением дизъюнкции от речевой ситуации и от ее локализаторов ("repère" в терминологии Кюльоли) и, с другой стороны, в дискурсивном регистре, в котором сообщаемый факт характеризуется определеннной темпоральной локализацией относительно $\mathrm{T}_{0}$.

\section{1. Нарративнье употребления: «претеритное» значение}

В нарративном регистре временное значение аориста связано с перфективом прошедшего, что согласуется с названием аориста в армянском (anc'eal katareal «прошедшее совершенное»). Действительно, значение перфектива прошедшего считается прототипическим для аориста как в армянском, так и во многих других индоевропейских языках, таких как ново-греческий [Vassilaki, Tsamadou 1995: 46], болгарский [Guentchéva 1990], персидский [Lazard 1957: 141; Lessan-Pezechki 2002], хинди [Montaut 2006а] и др.

3.1.1. Отсутствие темпоральной локализаџии речевой ситуащии (дизъюнкция от $T_{0}$ ). Это свойство является сущностной характеристикой нарративного регистра, в котором дискурсивные параметры отходят на второй план: временна́я отнесенность аориста к моменту речи может выражаться с помощью обстоятельств времени (иногда, когда я был молодым, в прошлом году, 10 дней назад, вчера и т. д.). Их функция состоит в том, чтобы определить временную отнесенность сообщаемого факта, позволяющую далее строить высказывание вне его связи с моментом речи. Таким образом, форма аориста оказывается наиболее отвлеченной от акта высказывания, позволяя говорящему в том числе сообщать о вымышленных событиях, особенно в письменной форме, оторванной от ситуации высказывания. 
Указанное свойство связано с одним из формальных признаков армянского аориста. В то время как перфект, состоящий из перфективного причастия и вспомогательного глагола в презенсе, локализован во времени речевой ситуации и выражает актуальность обозначаемого события в момент речи (результативное, экспериенциальное значения и т.д.), в синтетической форме аориста связь с моментом речи не выражена; она обозначает событие как таковое и переносит слушающего ко времени повествования.

Свойство временной дизьюнкции, или отсутствие связи с моментом речи, объясняет, почему темпоральная локализация события, выраженного формой аориста, маркируется в большинстве случаев контекстом, обстоятельствами времени (1) или сопутствующим предикатом в форме имперфекта, задающим временную рамку для события, выраженного аористом (2) и (4):

(1) U.jn opp Unı2ni teplup punutg, 2uunupunutg, uquunutig Epliu-

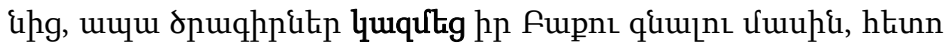

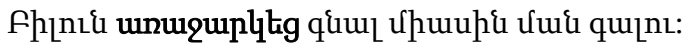

ayd $\bar{o} r=\partial \quad k u \check{s} \mathrm{o}=n$ erkar xosec

тот день=DEF Кушо=DEF долго говорить.AOR.3SG

šataxosec " patmec “ erewan-ic ‘

обсуждал.AOR.3SG рассказывал.AOR.3SG Ереван-ABL

apa cragir-ner kazmec" ir Bak'u

затем план-PL составить.AOR.3SG 3SG.GEN Баку

gnal-u masin, heto Bilu=n

переезжать-GEN об затем Билу=DEF

arajarkec $\quad$ gnal miasin man.gal-u

предложил-AOR.3SG идти вместе прогуляться-GEN

'B этот день Кушо долго говорил, что-то обсуждал, выяснял все о Ереване, затем поделился своими планами переехать в Баку, после чего Билу предложил прогуляться.' (Гурген Маари) ${ }^{16}$

16 Здесь и далее восточноармянские контексты цитируются по Восточноармянскому национальному корпусу (Eastern Armenian 


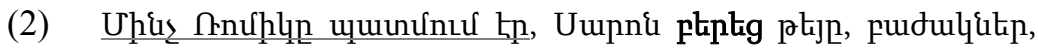

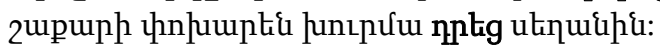

$$
\text { minč romik }=\partial \quad \text { patmum } \quad \bar{e} r \quad \text { saro }=n
$$

Пока Ромик=DEF говорить.PTC.PRS AUX.IPF.3SG Capo=DEF

ber-ec ‘ t'ey=ə bažak-ner šakar-i

приносить-AOR3SG чай=DEF чашка-PL caxap-GEN

p'oxaren xurma drec' setan- $i=n$

вместо финик класть.AOR.3SG стол-DAT=DEF

' $\mathrm{B}$ то время, как Ромик говорил, Саро принесла чай, чашки, а вместо сахара поставила на стол финики.' (Шаген Татикян)

При этом отсутствие эксплицитно выраженной временной рамки также возможно: аорист может выражать временную отнесенность сам по себе, поскольку в диалоге он функционирует как шифтерный оператор, маркирующий переход от дискурсивного регистра к нарративному:

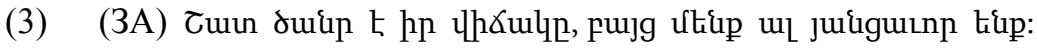

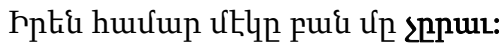

$\begin{array}{llll}\text { sat } & \bar{e} & \text { ir } & \text { vičak= }\end{array}$

очень тяжелый COP.PRS.1SG 3SG.GEN ситуация=DEF

bayc'menk' al hanc'avor enk'

но мы также виноватый COP.PRS.1PL

Ir hamar mekə ban ma $\check{c}^{\varsigma}=\boldsymbol{a r}$ - $\boldsymbol{a v}$

3SG.GEN для кто-то что-то INDEF NEG=делать.AOR-3SG

'Он в трудной ситуации, но мы и сами виноваты. Никто для него ничего не сделал.'

Свойство отсутствия связи с моментом речи $\left(\mathrm{T}_{0}\right)$, присущее нарративному регистру, является определяющим фактором ряда ограничений на употребление аориста. На это указывают многие лингвисты, например, Ж. Дум-Трагут: «Аорист не совместим с наречиями или словосочетаниями, обозначающими неопределенное время, такими как erbewē, orewē žamanak 'всегда, в любое

National Corpus: eanc.net); перевод на русский язык автора данной статьи. Примеры без указания источника основаны на элицитации. 
время', hačax 'часто', etc.» [Dum-Tragut 2009: 231]. Тем не менее, обращение к Восточноармянскому национальному корпусу (Eastern Armenian National Corpus: eanc.net) дает 48 употреблений hačax 'часто' и 50 примеров erbewē 'когда-нибудь' в сочетании с аористом. Таким образом, если такое ограничение и существует, оно является скорее тенденцией, чем правилом: временная дизъюнкция между сообщаемым фактом в аористе и $\mathrm{T}_{0}$ предполагает, что событие может иметь автономную временную локализацию, неопределенную относительно $\mathrm{T}_{0}$ независимо от того, определяется ли она контекстом или нет (см. пример 3, в котором аорист формирует собственную темпоральную референцию). Некоторые примеры, в которых аорист сочетается с hačax и erbewē, будут проанализированы ниже в разделах 3.1.2 и 3.1.3.

3.1.2. Компактное и целостное событие. Второе свойство, которое также рассматривается как характеристика аориста в современном греческом $^{17}$, это, возможно, то, что побуждает лингвистов интерпретировать аорист как недуративное время, на временной оси представляемое в виде точки, в то время как имперфект представляется в виде интервала. В случае с непредельными событиями (непредельность может быть свойством лексического значения глагола или его контекстным проявлением) имперфект задает временную рамку (интервал между начальной и конечной границами события), в то время как аорист представляется точкой с неопределенными границами, поскольку ориентирован на преставление события как единого целого:

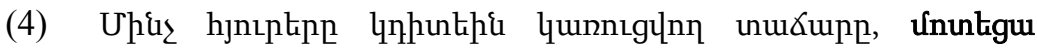
大upunupuuptinhis:

$$
\text { minč hyur-er }=0 \quad \text { k.dit-ein }
$$

пока гость-PL=DEF смотреть.FUT/CONJ-3PL

$$
\begin{array}{lll}
\text { kaŕuc'vot } & \text { tačar }=\partial & \text { motec }^{\text {s }} \boldsymbol{a} \\
\text { строящийся } & \text { храм=DEF } & \text { приближаться.AOR-1SG }
\end{array}
$$

${ }^{17}$ «С точки зрения выражения вида, значение основы аориста можно представить как не поддающийся делению компактный интервал. Соответственно он воспринимается как целое, и обозначаемое событие понимается обобщенно, не допуская выделения в его составе начала, середины и конца» [Vassilaki, Tsamadou 1995: 46]. 
čartarapet $-i=n$

архитектор-DAT=DEF

'В то время как гости рассматривали строящуюся церковь, я подошел к архитектору.' (Ерджаник Караханян)

A. Маркарян [Markarian 2004: 434], со ссылкой на [Abeghyan 1965], утверждает, что аорист выражает событие не имеющее длительности, в то время как А. Джиорджи и С. Арутюнян [Giorgi, Harutyunian 2011: 101] говорят, что аорист сочетается исключительно с точечными действиями. Очевидно, что это свойство касается не реальной длительности события, поскольку аорист сочетается со стативными и дуративными глаголами, как в (7), а также с итеративностью. Несовместимость с наречием hačax 'часто', на которую указала Ж. Дум-Трагут, в действительности является тенденцией, обусловленной признаком компактности, присущим аористу, а не ограничением на сочетаемость аориста с показателями временной неопределенности. Это объясняет, почему ограничения такого рода не являются абсолютными, ср. примеры (5-6):

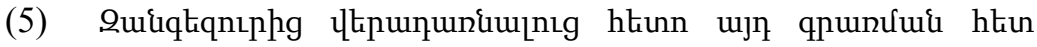

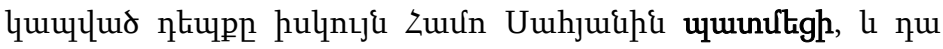

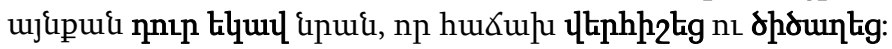

zangezur-ic" veradarnal-uc' heto ayd

Зангезур-ABL возвращаться-ABL после то

grarm-an het kapvac depk'=ə iskuyn

запись-GEN с связанный событие $=$ DEF действительно

hamo sahyan- $i=n \quad$ patmec' $-i \quad$ ew da

Хамо Сахьян-DAT=DEF рассказывал.AOR-1SG и это

aynk'an dur.ek-av nran or hačax

настолько нравиться-AOR.3SG 3SG.DAT что часто

verhišec" $u$ cicalec

пересказывать.AOR.3SG и смеяться.AOR.3SG

'Возвратясь из Зангезура, я действительно подробно рассказывал Хамо Сахьяну все обстоятельства, связанные с этой записью, и ему это так понравилось, что он часто пересказывал их и смеялся.' (Ваагн Давтян) 


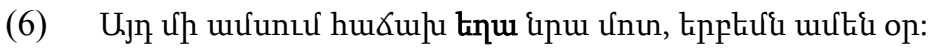

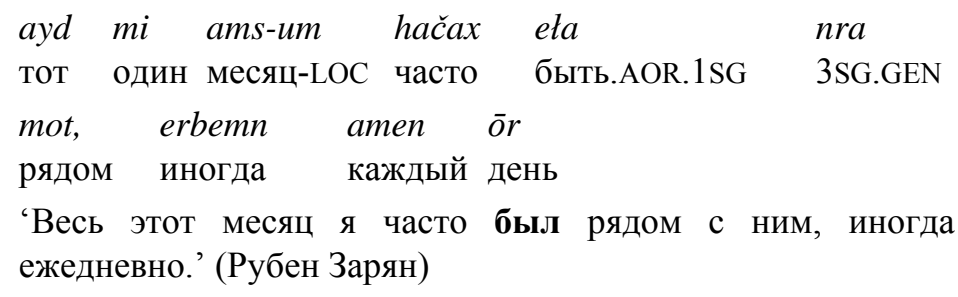

Событие может быть представлено как компактное даже в том случае, если глагольная группа имеет итеративное или дуративное значение. Это позволяет рассматривать глагольные времена скорее как операторы, которые обуславливают семантику высказывания, нежели как маркеры, кодирующие референтную ситуацию или контекст. Именно это прослеживается в примере (6), где аорист позволяет употреблить стативный глагол для описания динамического события.

3.1.3. Динамическое событие. Признак компактности тесно связан с признаком динамичности события (в противовес стативным и результативным событиям), особенно в нарративном регистре. В примере (7), дуративные события, обозначаемые глаголами kangnel 'стоять' и nayel 'смотреть', представляются как компактные события, включенные в нарративную цепочку:

(7) tqp quiqqukg, quiquitig, fuujtg, fuujtg fliq, huilqund

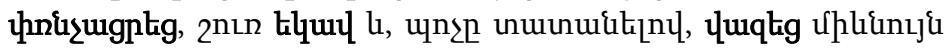

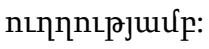

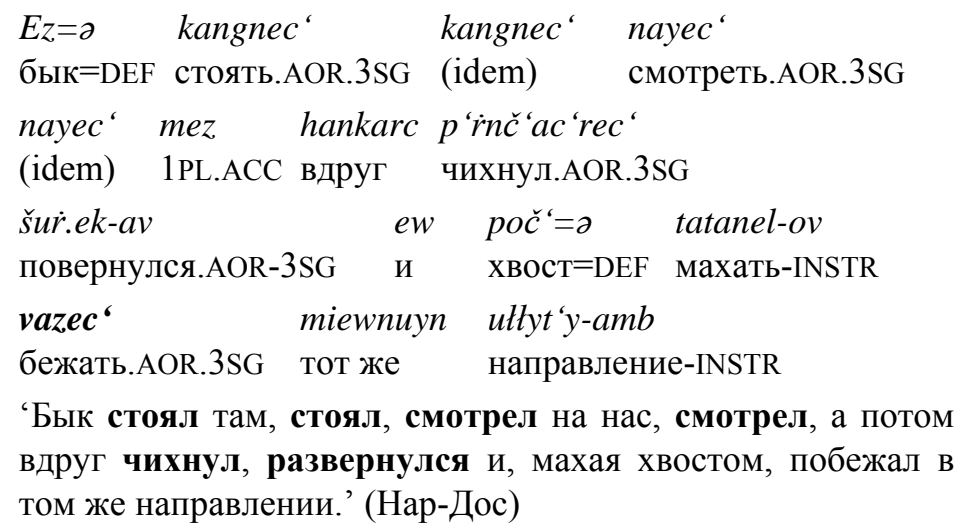


Дуративная семантика стативных глаголов kangnel 'стоять' и nayel 'смотреть', усиленная редупликацией, создает эффект ожидаемости события, которое можно определить через отрицание (остановка, прекращение движения); здесь стативный глагол выражает состояние, которое контрастирует с тем, что ожидалось (ожидалось, что бык продолжит движение) и, таким образом, имеет коннотацию динамического события.

3. Генчева [Guentchéva 1990: 84] считает событийность (l'occurrence d'événement) базовой чертой аориста в болгарском. В действительности это значение связано со значением претерита, которое упоминалось выше в отношении ряда индоевропейских языков. А. Маркарян [Markarian 2004: 436] характеризует армянский аорист как время, которое обеспечивает поступательный ход повествования. По мнению Ж. Дум-Трагут [Dum-Tragut 2009: 231], армянский аорист употребляется как основная нарративная форма, особенно для выражения ряда последовательных действий/ситуаций и только в тех случаях, когда говорящий был их свидетелем.

Компактность события связана в первую очередь с акциональным классом достижений (achievements), включающим, согласно Вендлеру, динамическое и предельное действия. Достижения обычно предполагают контекст с несколькими хронологически упорядоченными событиями. Таким образом, аорист является в первую очередь временем хронологической последовательности событий. См. (1), а также (8):

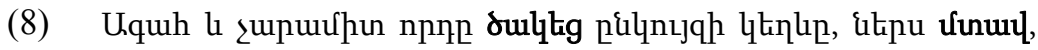
uhqnıln lipuul, nuunuplitg, quuntig ns tipqtig $\langle\ldots\rangle$

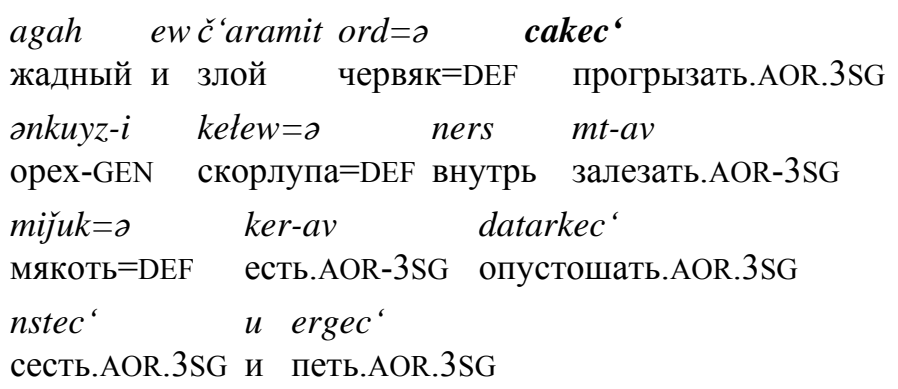


'Жадный и злой червяк прогрыз скорлупу ореха, залез внутрь, съел мякоть, опустошил (орех), уселся и начал петь' ${ }^{18}$ (Атабек Хнкоян)

Согласно А. Монто [Montaut 2006b: 188], аорист в хинди представляет собой простую последовательность завершенных процессов без их оценки говорящим; перфект напротив, предполагает оценку процесса, подводящего итог прошедшему действию. Это полностью соответствует ситуации в армянском ${ }^{19}$.

Сочетание свойств компактности и событийности объясняет, почему последовательность форм аориста часто обозначает хронологическую последовательность, что само по себе, строго говоря, не является базовым значением аориста и не может ограничивать его употребление. Это подтверждается корпусными данными, содержащими многочисленные примеры употребления аориста вне хронологической последовательности событий, так что выбор формы аориста определяется лексическим классом глагола (ср. (7), где первые два стативных глагола выражают синхронные события), контекстом логического (а не хронологического) следования.

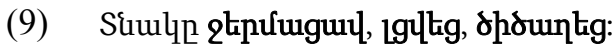

$\begin{array}{ll}\text { tnak }=\partial \quad \text { jermac'- } a v & l c^{\prime} \text { vec } \\ \text { домик }=\mathrm{DEF} \text { согреваться.AOR-3SG } & \text { заполняться.AOR.3SG }\end{array}$

${ }^{18}$ В армянском буквально 'спел', но нарративная структура предполагает последовательность динамических процессов, которая придает аористу ингрессивное значение.

${ }^{19}$ Cp. пример из [Barchian 2003: 304]: армянский профессор рассказывает о своем приезде в Париж, где на вокзале его никто не встретил (в переводе). Там ночью мы всю ночь пировали (РFТ) по случаю расставания, я пошел спать (РFT) в 7 утра, в 8:30 я сел (РFТ) в скоростной поезд и приехал (РFТ) в час дня на Лионский вокзал. (Никого не видел).// Я беспокоился (AOR) и подумал (AOR), он наверно в пути, может, появится. Последовательность форм перфекта создает кумулятивный эффект, результатом которого является состояние, в котором в прошлом пребывал говорящий. Формы аориста появляются, когда дело уже не в итогах того, что предшествовало приезду, а в конкретном действии. 
cicałec

улыбаться.AOR.3SG

'Дом согревался, заполнялся, улыбался.' (Мкртич Саркисян)

В примере (9) метафорическое употребление глаголов объясняет, почему хронология оказывается нерелевантной. Можно также привести примеры цепочек онтологически связанных глаголов, создающих кумулятивный эффект, который не затрагивает их событийного значения; такие цепочки могут выражать эмфазу, когда все глаголы в цепочке призваны описывать одно и то же поведение, ср. (10):

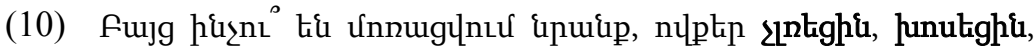

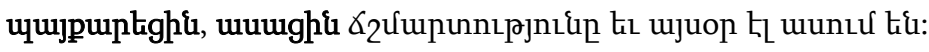

$\begin{array}{llll}\text { Bayc 'inč } u & \text { en } & \text { morac 'vum } & \text { nrank' } \\ \text { но почему } & \text { AUX.3PL } & \text { забывать.PASS.PTC.PRS } & \text { тот }\end{array}$

ov-k'er $\quad \check{c}$ ' $=$ liec '-in $\quad$ xosec'-in

кто-PL NEG=молчать.AOR-3PL говорить.AOR-3PL

payk'arec'-in asac'-in čšmartut'yun=o ew

бороться.AOR-3PL говорить.AOR-3PL правда=DEF и

aysōr è lasum en

сегодня также говорить.PTC.PRS AUX.PRS.3PL

'Но почему предают забвению тех, кто не молчал, кто говорил, кто боролся, кто высказывал правду и продолжает еe высказывать сегодня? («Azg Daily», 2008.04.05)

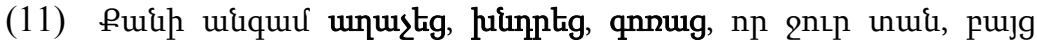

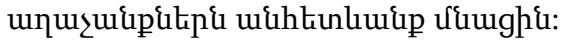

$K^{\prime a n i}$ angam atačec" xndrec

сколько раз умолять.AOR.3SG просить.AOR.3SG

gorac" or jur tan bayc “

кричать.AOR.3SG чтобы воду дать.3PL но

ałač'ank'-ner=n anhetewank' mnac'-in

мольба-PL=DEF тщетный остаться.AOR-3PL

'Сколько раз он умолял, молился, кричал, чтобы ему дали воды, но его мольбы остались тщетны.' (Шаген Татикян) 
Некоторые глаголы часто встречаются вместе и ведут себя как устойчивые словосочетания, например, 'пить, есть, пировать':

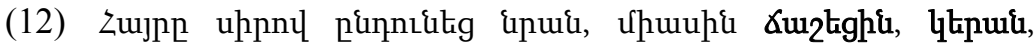

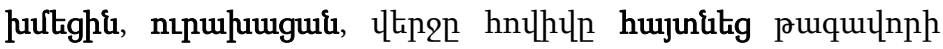
huanhppp, wukinul $\langle\ldots\rangle$

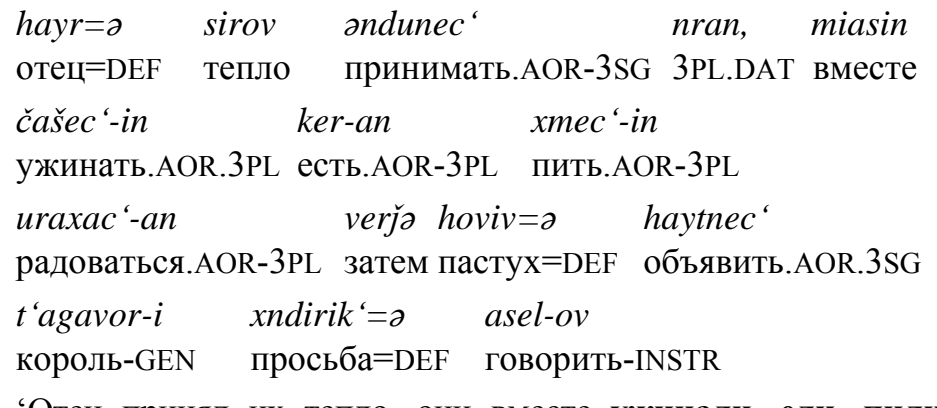

'Отец принял их тепло, они вместе ужинали, ели, пили, пировали, а затем пастух объявил волю короля, сказав...' (Раффи)

Как видно из приведенных примеров, хронологическая последовательность событий в аористе свойственна дискретным событиям, обеспечивающим поступательный ход повествования, но она не является определяющей чертой аориста, поскольку аорист допускает и последовательность неограниченных событий, в том числе и дуративных, не столько выстраивая события в хронологической последовательности, сколько образуя событие сложного состава. Пример (12) показывает, что оба типа последовательностей могут совмещаться: события (отеи тепло их принял, они вместе ужинали, пастух объявил волю короля) хронологически упорядочены, а глаголы пили и пировали следуют за ели и дробят комплексное действие ужинали, с тем, чтобы сделать рассказ более выразительным.

Последовательность глаголов, стоящих в аористе, может передавать и другие типы отношений между описываемыми событиями, иногда - эксплицитно (ср. henc “'как только' в (13)), иногда - через контекст (ср. отношения причинности в (14)):

(13) Zu. Llikg upunuuwitighp updoup huulqugu: 
ha henc' artasanec'-ir prc-ar

да как_только читать.AOR-2SG закончить.AOR-2SG

haskac'-a

понимать.AOR-1SG

'Да! Как только ты кончил (его) читать, я понял [что это было не твое стихотворение].' («Aravot Daily», 2006.11.18)

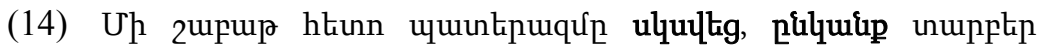
nuiqưrurquinitip:

Mi šabat' heto paterazm=o sksvec

одна неделя после война=DEF начинаться.AOR.3SG

onk-ank، tarber razmačakat-ner

попадать.AOR-1PL разный фронт-PL

'А через неделю началась война, и мы оказались на разных фронтах.' (Аршак)

Общей чертой этих типов отношений между событиями в аористе является то, что они не имеют локализации относительно речевой ситуации. Последовательность событий задается через контекст и/или с помощью лексической семантики. Таким образом, типичная хронологическая последовательность 'пришел, увидел, победил' является лишь одним из способов локализации последовательных событий, выраженных аористом.

Свойство событийности также объясняет, почему упомянутая Ж. Дум-Трагут [Dum-Tragut 2009] несовместимость аориста с erbewē 'когда-нибудь; никогда' не является абсолютной. В утвердительном предложении, появление аориста в сочетании с erbewe предполагает отрицательную форму глагола и сигнализирует о том, что событие не имело места в течение данного промежутка времени. Глаголы могут быть достижениями по Вендлеру (недуративными):

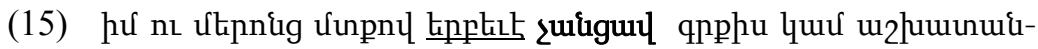
phu hungtinnц tu.z-hi nhưl $\langle$ L...

\begin{tabular}{|c|c|c|c|}
\hline$u$ & meronc & $m t k^{\prime}-o v$ & erbewē \\
\hline $\begin{array}{l}\text { SG.GEN и } \\
'=a n c^{\prime}-a v\end{array}$ & мой.PL.GEN & $\begin{array}{l}\text { yM-INSTR } \\
\text { grk }^{\prime}-i=s\end{array}$ & никогда \\
\hline Ip & AOR -35 & -GEN & OSS \\
\hline
\end{tabular}


ašxatank' $-i=s$

harc'-er-ov

X. H. $-i=n$

работа-GEN=1POSS

вопрос-PL-INSTR X. H.-DAT=DEF

dimel

обращаться

'Мне и моим родным, никогда не приходило в голову обратиться к Х. Г. по собственным делам.' (Армен Шекоян)

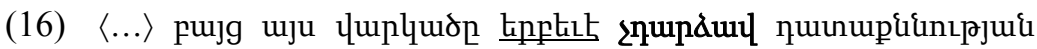
unupluu $\langle\ldots\rangle$

bayc' ays varkac $=\partial$ erbewe $\bar{c} ‘=$ darj-av

но эта теоря=DEF никогда $\mathrm{NEG}=$ становиться.AOR-3SG

datak'nnut'y-an ararka

проверка-GEN объект

'Однако эта теория никогда не подвергалась проверке.' («Aravot Daily», 2003.11.19)

Однако аорист, представляющий событие как компактное, может быть употреблен даже с дуративными глаголами. Пример (17) может быть переведен с использованием фазового глагола (поддаться/поддаваться отчаянию), что свидетельствует о компактности события, выраженного аористом:

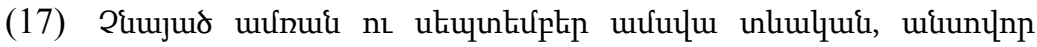

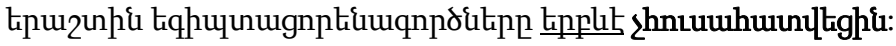

čnayac amr-an $u$ september ams-va несмотря на лето-GEN и сентябрь месяц-GEN

tewakan, ansovor erašt- $i=n$

долгая необычная засуха-DAT=DEF

egiptac'orenagorc-ner $=\partial$ erbewe

кукуруз.сборщик-PL=DEF никогда

$\check{c} "=$ husahatvec ${ }^{\prime}$-in

$\mathrm{NEG}=$ отчаиваться.POSS.AOR $=3 \mathrm{SG}$

'Несмотря на исключительно долгую засуху летом и в сентябре, сборщики кукурузы никогда не отчаивались.' («Зангезур», 1986.10.07) 


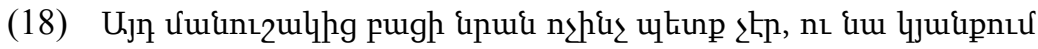

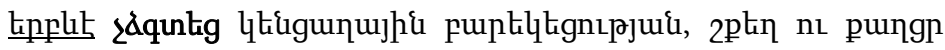
ljuilup zulqulquilig no zhiunptig $\langle\ldots\rangle$

Ayd manušak-ic' bac'i nran oč inč' petk'

эта фиалка-ABL кроме 3SG.DAT ничего нужно

$\check{c}^{\prime}=\bar{e} r \quad u$ na kyank'-um erbewe

$\mathrm{NEG}=\mathrm{COP} . \mathrm{IPF} .3 \mathrm{SG}$ и $3 \mathrm{SG}$ жизнь-LOC никогда

$\check{c}^{\prime}=$ jgt-ec' kenc'alayin barekec 'ut' $y$-an

$\mathrm{NEG}=$ желать-AOR3.SG материальный благополучие-GEN

šk'et $u k^{\prime a t c}$ 'r kyank' $\check{c}^{\prime}=$ aknkalec' $u$

легкий и сладкий жизнь $\mathrm{NEG}=$ ожидать и

$\check{c} "=p$ 'ntrec $"$

$\mathrm{NEG}=$ искать. $\mathrm{AOR}=3 \mathrm{SG}$

'Кроме этой фиалки ей ничего не было нужно, и за всю свою жизнь она никогда не соблазнилась материальным благополучием, не искала легкой шикарной жизни и не надеялась на нее.' (Ваагн Давтян)

Таким образом, когда erbewē характеризует длинный временной промежуток, как в (18), за всю свою жизнь, вне зависимости от семантики глагола, аорист представляет процесс как событие. В (17) и (18) событийность можно было бы глоссировать как 'этого не случилось'. Утверждается (или отрицается) именно представление положения дел как единого события.

Как было показано, событийность аориста, тесно связанная с компактностью и отсуствием локализации относительно момента речи, имеет разнообразные семантические реализации, которые позволяют выходить за сформулированные в грамматиках ограничения; эти ограничения необходимо рассматривать как частные проявления свойства событийности.

3.1.4. Модальное значение. В грамматиках часто упоминается модальное значение аориста. 3. Генчева [Guentchéva 1990: 94, 107] отмечает, что аорист отсылает к событию, которое несомненно имело место, которое не вызывает сомнений, и это отличает его от медиативного/эвиденциального времени. Ж. ДумТрагут [Dum-Tragut 2009: 231] предполагает, что аорист употре- 
бляется только в том случае, если говорящий является свидетелем события.

В действительности, это значение не релевантно для нарративного регистра в армянском, где уверенность в том, что событие имело место, и наличие личного свидетельства не являются маркированными признаками аориста, на что указывают многочисленные примеры, в частности, (20) и (29-36). В большинстве случаев, это свойство аориста упоминается в грамматиках как отличительный признак аориста по контрасту с временами, которые используются при выражении сомнения, неуверенности, отсутствия личного свидетельства (эвиденциальное время или даже плюсквамперфект). Однако это противопоставление касается только дискурсивного регистра; нарративный же регистр, по-видимому, в этом отношении не маркирован.

\section{2. Аорист в дискурсивной ситуации}

Дискурсивная ситуация допускает употребления аориста, сходные с его нарративными употреблениями, как показывает пример (19), где наблюдается изменение регистра внутри предложения (отмечено знаком «//»):

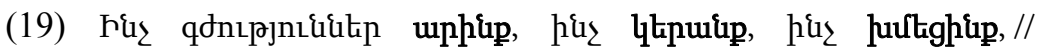

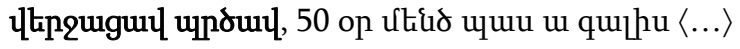

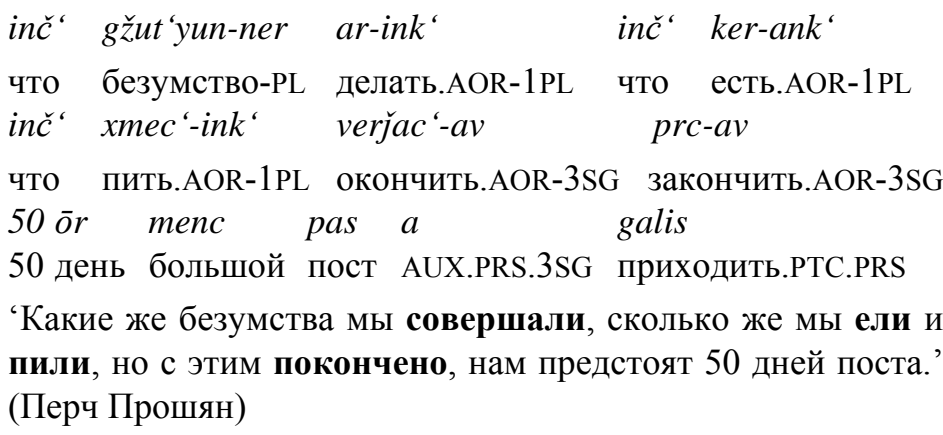

Первая последовательность событий («мы ели/пили») является нарративной, в то время как синтагма «с этим покончено» обеспечивает переключение на дискурсивный регистр, которому свойственна темпоральная локализация в речевой ситуации и субъективным отношением говорящего («но вот, к сожалению, ситуация изменилась, и сейчас все по-другому»). 
В (19) переключение с одного регистра на другой достаточно очевидно из контекста, однако в дискурсивной ситуации не всегда просто обнаружить, в какой момент говорящий переходит на нарративный регистр. Так, например, фраза verjapes hasa 'наконец я приехал' однозначно односитса к дискурсивному регистру, в то время как фраза tak'siov eka 'я приехал на такси' может относиться как к дискурсивному, так и к нарративому регистру в зависимости от контекста (с одной стороны, например, как реакция на предположение собеседника о том, что говорящий не мог приехать, с другой стороны, в контексте типа «ты знаешь, сегодня я приехал на такси, потому что в прошлый раз автобус ехал слишком долго»).

Детальный анализ параметров, которые позволяют различать дискурсивные и нарративные употребления аориста, выходит за рамки данной статьи. Данный раздел, прежде всего, посвящен анализу употреблений аориста, которые предполагают локализацию относительно речевой ситуации. Мы попытаемся показать, что: локализация аориста относительно речевой ситуации определяет ряд модальных значений, отличных друг от друга, но связанных с фундаментальными свойствами аориста; эти значения оказывают влияние на видовые характеристики. Это позволит нам показать, что значение «будущего», реализуемое в некоторых предложениях с аористом, органично связано с остальными дискурсивными значениями аориста и не является «парадоксальным» значением.

3.2.1. Локализаџия относительно речевой ситуации и модальные значения, свойственные дискурсивному регистру. Дискурсивная ситуация предполагает наличие точек отсчета, основными из которых являются «момент речи» и «говорящий», обозначаемых в теории «лингвистики высказывания» Кюльоли как $\mathrm{T}_{0}$ и $\mathrm{S}_{0}$ соответственно. Как было показано выше, характерной чертой аориста является отсутствие локализации относительно речевой ситуации. Тем не менее, аорист может появляться в дикурсивных ситуациях. Сочетание этих двух, на первый взгляд несоместимых признаков приводит к появлению у форм аориста некоторых модальных значений.

Согласно Бенвенисту, в дискурсивном регистре, в отличие от нарративного, истинность утверждения определяется говорящим, что делает возможным переход к таким модальным значе- 
ниям как комментарий, личная оценка, эмфаза или сильное утверждение, см. (19) и (20).

Событийность аориста делает возможным специфический тип утверждения, в котором событие представляется как произошедшее помимо воли говорящего, но осознаваемое им. Это позволяет выразить с помощью форм аориста модальную коннотацию осознавания, даже внезапного осознавания действия, как в примере (21).

Некоторые контексты и семантика отдельных типов глагола могут способствовать проявлению того или иного значения. Более того, такие часто приписываемые аористу в грамматиках черты, как «событие, наблюдаемое в момент речи», «личное свидетельство», «достоверность события» возникают именно под влиянием таких контекстов или семантических типов, демонстрируя лишь некоторые из возможных значений аориста.

Первый случай иллюстрирует следующий пример:

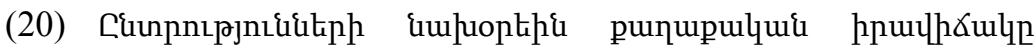

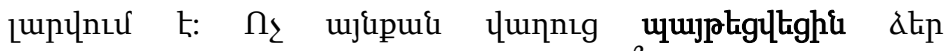

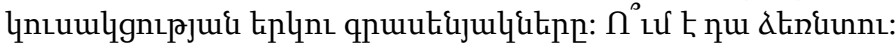

Ontrut' 'yun-ner-i naxōre-i=n $k$ 'ałak'akan

выбор-PL-GEN канун-DAT=DEF политический

iravičak=ə larvum ō $\bar{e}$

ситуация=DEF напрягаться.PTC.PRS AUX.PRS.3SG не

aynk'an vat-uc' payt'ec'vec'-in jer

настолько время-ABL взрывать.AOR-3PL 2PL.GEN

kusakc'ut'y-an erku grasenyak-ner=o um $\bar{e}$

партия-GEN два офис-PL=DEF. кому COP.PRS.3SG

da jerintu

это выгодный

'Накануне выборов ситуация сложилась напряженная. Не так давно были взорваны два оффиса вашей партии. Кому это выгодно?’ («Aravot Daily», 2007.05.10)

Здесь не «наблюдается» ни само событие, ни его результат, но событие представляется как значимое для аргументации, допуская ответную реакцию. Эти признаки ассоциируются с сильным утверждением. 
Значение, которое интерпретируется в грамматиках как «личное свидетельство» или «достоверность», можно проиллюстрировать следующим примером:

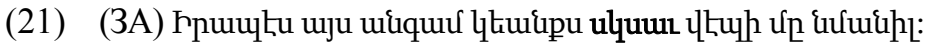

\begin{tabular}{|c|c|c|}
\hline $\begin{array}{l}\text { irapēs } \\
\text { действительно }\end{array}$ & $\begin{array}{l}\text { ays } \\
\text { ЭТОТ }\end{array}$ & $\begin{array}{l}\text { angam } \\
\text { pa3 }\end{array}$ \\
\hline
\end{tabular}

sks-aw vep-i mo nmanil

начинать.AOR-3SG роман-DAT INDEF напоминать

'Моя жизнь уже действительно стала похожа на роман.'

В (21) событие представляется как дискретное с помощью обстоятельства времени ays angam 'на этот раз'. Говорящий осознает, что событие имеет место, и сразу же сообщает об этом. В этом употреблении аорист разделяет ряд общих свойств с эвиденциальным временем/адмиративом ${ }^{20}$ : осознание процесса как одновременного с актом высказвания также является одним из модальных признаков, характерных для западноармянского эвиденциального прошедшего в дискурсивном регистре (миративное значение), о чем свидетельствует возможность поставить глагол в примере (21) в плюсквамперфект, ср. (21a):

\begin{tabular}{|c|c|c|c|c|}
\hline $\begin{array}{l}\text { (21a) irapēs } \\
\text { действительно }\end{array}$ & $\begin{array}{l}\text { ays } \\
\text { ЭТОТ }\end{array}$ & $\begin{array}{l}\text { angam } \\
\text { pa3 }\end{array}$ & $\begin{array}{l}\text { kyank }^{\prime}=s \\
\text { жизнь }=1 \mathrm{POS}\end{array}$ & \\
\hline skser & $\bar{e} r$ & & $v \bar{e} p-i$ & $m ə$ \\
\hline $\begin{array}{l}\text { начинать.PTC.EVID } \\
\text { nmanil }\end{array}$ & A AUX & X.PST.3SG & роман-DAT & INDEF \\
\hline
\end{tabular}

напоминать

'В этот период действительно моя жизнь стала похожа на роман.'

В дискурсивной ситуации с отнесенностью к моменту речи $\mathrm{T}_{0}$, как в (21), система допускает противопоставление аориста и эвиденциального времени, при котором последнее используется для выражения сильного удивления, неожиданности, чрезвы-

20 Это может объяснить, почему в хинди адмиративное значение выражается аористом, а не перфектом. 
чайного характера события. Но как только высказывание переводится в $\mathrm{T}_{-1}$, как в примере (21a), и выводится за рамки дискурсивной ситуации, такое противопоставление становится невозможным. Это показывает, что описанные значения на самом деле допустимы только для дискурсивного регистра [Donabédian 1996].

Два рассмотренных выше свойства аориста обусловливают модальные значения аориста, зависящие от глагольной семантики, контекста, а в ряде случаев - от устойчивых словосочетаний. Некоторые из таких значений отмечались и для других языков:

\section{1) Глаголы внутреннего состояния (ЗА)}

\section{(22) Uinoptigur}

anōt'ec'-ay

голодать.AOR-1SG

' Я голоден (проголодался)'
(23) 2uiùnuuguu janjrac'-ay насыщать.AOR-1SG

'Мне надоело! ${ }^{21}$,

Это значение сходно с употреблением глаголов внутрен-

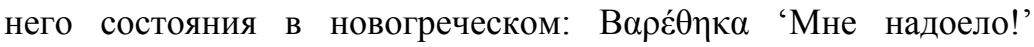
[Vassilaki, Tsamadou 1995].

\section{2) Глаголы изменения состояния (ЗА и ВА)}

(24) Upitig

mt'nec'

темнеть.AOR.3SG

'Стемнело.'

3) Значение будущего времени. Это значение упоминается в [Dum Tragut 2009: 232] как ингрессивное значение глаголов движения (gnac i $i)$, и соответствует термину аорист антищипащии

${ }^{21}$ Кроме того, даже если эти высказывания и обнаруживают сходство с эвиденциальным временем, можно выделить минимальные пары, в которых anōt'ec 'ay (аорист) и anōt'ec 'er em (эвиденциальное) не являются взаимозаменимыми. Если в последнем акцент делается на причинности, то в аористе дается простая констатация без установления последовательности событий. 
(aoriste d'anticipation), который используется в [Lessan-Pezechki 1998] для персидского языка.

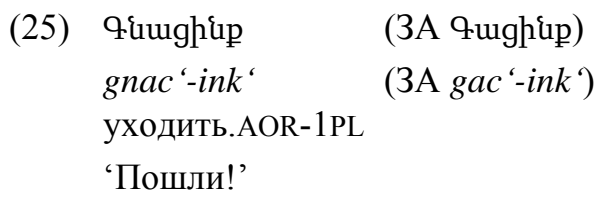

Это значение отражает свойство, которое отмечается в [Vassilaki, Tsamadou 1995] применительно к инхоативному значению аориста глаголов состояния или изменения состояния, глаголов, которые обозначают завершение физического процесса

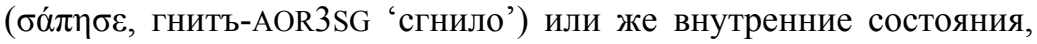
как в примерах (22) и (23).

Только такие специфичные для дискурсивного регистра высказывания (со значениями осознания или проспектива) согласуются со значением «совпадения с моментом речи», которое указывается в грамматиках как одна из характеристик аориста. К сожалению, это ограничение не упоминается ни в одной грамматике. Как видно из приведенных примеров, модальные особенности таких употреблений связаны с видовой спецификой: изменение состояния составляет основной компонент всех этих значений.

3.2.2. Астектуальные особенности аориста, связанные со свойством компактности события. Ж. Дум-Трагут [Dum Tragut 2009: 231], не использует понятие «дискурсивный регистр» и отмечает, что в прямой речи аорист обозначает действие, которое произошло непосредственно перед моментом речи, и результат которого можно наблюдать в момент речи. Условие непосредственного предшествования, если его понимать буквально, не соблюдается во множестве случаев. В действительности, близость к моменту речи связана с событийным значением аориста, которое позволяет говорящему зафиксировать событие как таковое, в то время как перфект фиксирует результат события $^{22}$ в $\mathrm{T}_{0}$ (ср. дополнение к переводу в скобках):

22 Под признаком «результат, наблюдаемый в момент речи», несомненно, понимается то же самое, но эта формулировка не вполне 
(26) Zugn lipup, unduin:

$\begin{array}{lll}h a c^{\prime}=d & k e r-a r & p r c-a r \\ \text { хлеб=2POSS } & \text { есть.AOR-2SG } & \text { заканчивать.AOR-2SG }\end{array}$

'Ты кончил есть? [Bсе?]'

(26a) Zugn lititi ${ }^{\circ}$ tur:

hac $=d \quad$ kerel es

хлеб=2POSS есть.PTC.PFT AUX.PRS.2SG

'Ты наелся? [ты больше не голоден? Я могу убрать со стола?]'

Этот контраст проявляется при различных семантических типах глагола (например, в (26) употреблен глагол, относящийся к акциональному классу деятельностей по Вендлеру), а не только в хорошо известном контексте с глаголами класса достижений типа 'приезжать, приходить', где аорист имеет значение достижения предела (это сделано, закончено, мне удалось это сделать; ср. (27)), в то время как перфект обозначает результат (ср. перевод «он здесь» в (27a)):

(27) (3A) y, tinguuutu huuw]

verjapes has-a

наконец достигать.AOR-1SG

'Наконец я приехал.'

Пример (27) может иметь две событийные интерпретации: «Все, я это сделал» (акцент на завершении процесса, который мы, вслед за Кюльоли, обозначаем как Qnt), или же «Это состоялось, вот что я сделал» (подчеркнутая значимость номинируемого свойства, акцент на природе состоявшегося действия, в теории Кюльоли обозачается как Qlt). Напротив, в примере (27a) перфект допускает только результативную интерпретацию:

(27a) (3A) प.tequultu huuwd k:

удачна и с трудом поддается интерпретации, поскольку данный признак обычно используется для описания результативного значения перфекта. 
$\begin{array}{lll}\text { verjapēs } & \text { hasac } & \overline{\boldsymbol{e}} \\ \text { наконец } & \text { достигать.PTC.PFT } & \text { AUX.PRS.3SG }\end{array}$

'Наконец-то он пришел («он здесь», результативный перфект) ${ }^{23}$,'

Событийное значение может проявляться также в стативных глаголах, как это видно в примере (28), где отчетливо выражен признак интенциональности в переходе к действию, влияющий на семантику глагола и позволяющий интерпретировать его как событийный глагол:

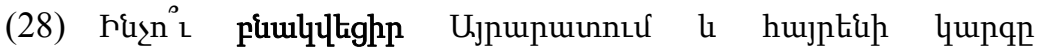
huuiqupinghp $\langle\ldots\rangle$

inč' $u$ bnakvec'-ir ayrarat-um ew hayreni

почему обитать.AOR-2SG Айрарат-LOC и предков

karg $=\partial \quad$ xangarec'-ir

закон=DEF нарушать.AOR-2SG.

'Как это ты жил [решил жить] в Айрарате и пренебрегаешь законами наших предков?' (Саркис Арутюнян)

В подобных примерах значение компактного события проявляется не только через признаки динамичности и предельности, но и через акцентирование одной из границ процесса, начальной (инхоативное значение в (21-24)) или конечной (26-27). Как видно, независимо от лексического класса глагола по типологии Вендлера (состояния, деятельности, свершения, достижения), употребление аориста приводит к представлению события как достижения. Можно предположить, что этот же механизм объясняет то, что в новогреческом называют $и н$ хоативным значением или результативным состоянием пре-

${ }^{23} \mathrm{~B}$ изолированных предложениях третье лицо согласуется с употреблением перфекта, cp. (27a) ( $\mathrm{S}_{0}$ отмечает в ситуации что-то, касающего третьего лица), а первое лицо - c аористом $\left(\mathrm{S}_{0}\right.$ делает утверждение о событии в момент, когда оно происходит). В более длинных контекстах совмещение первого лица с перфектом и третьего-с аористом, безусловно, также допустимы. 
дельныхх глаголов [Vassilaki, Tsamadou 1995]: вне зависимости от лексической семантики глагола, использование аориста приводит к акцентированию границ события.

В случаях, когда в фокусе оказывается событие как таковое, ср. (28), сама природа события, сам факт того, что такое событие произошло (то есть, по Кюльоли, когда имеет место скорее квалификативная операция $(Q l t)$, задающая понятие как таковое, чем квантитативная операция, определяющая конкретное проявление процесса с его границами $(Q n t))$, событие предстает как компактное, как единое целое, а значения аориста сливаются со значениями нарративного регистра.

Два рассмотренных проявления значения компактного события в аористе (номинация события с акцентированием либо одной из его границ $(Q n t)$, либо выражаемого глаголом понятия $(Q l t))$ проявляются также в контексте «если вдруг...», связанном со значением будущего времени, встречающимся у форм аориста.

3.2.3. Неактуализированный аорист и так называемое значение будущего. Способность аориста выражать будущее событие часто представляется как экзотическая черта армянского языка. Как будет показано в данном разделе, это значение аориста характерно и для других языков ${ }^{24}$. Более того, оно прямо выводится из инвариантных свойств аориста, определенных и проиллюстрированных выше. Мы попытаемся показать, что термин «будущее» - это не самый удачный для этого значения.

3.2.3.1. Постановка вопроса и состояние его изучения. Примеры, представленные в данном разделе, заимствованы из [Dum-Tragut 2009: 231], где им сопутствует следующий коммен-

${ }^{24}$ Cp. [Lessan-Pezechky 2002] с описанием персидского мате-

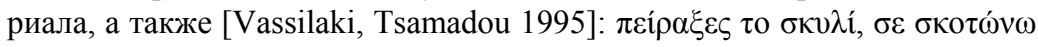
'ты поранил собаку, я тебя убью' (Если вдруг поранишь собаку, я тебя

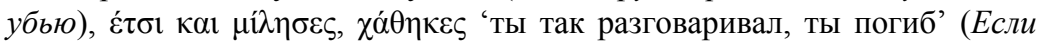
вдруг будешь говорить таким образом, погибнешь), где протасис выражается аористом, а аподосис может выражаться как настоящим временем, так и аористом, как в армянском языке. В русском эту роль выполняет перфектив настоящего времени (см. русский перевод примера 30), что могло повлиять на интерпретацию соотвествующей формы в [Giorgi, Harutyunian 2011]. 
тарий: «В условных придаточных предложениях аорист часто используется для обозначения единичного неожиданного действия в будущем, либо для повторяющегося неожиданного действия ${ }^{25}$ :

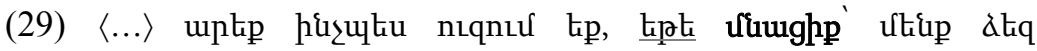
qu्uzunumultip:

$\begin{array}{llll}\text { arek' inčpes }^{\prime} & \text { uzum } & e k^{\prime} & e^{\prime} e \\ \text { делайте как } & \text { хотеть.PTC.PRS } & \text { AUX.PRS.2PL } & \text { если } \\ \text { mnac'-ik' } & m e n k ' j e z & k . p a s ̌ t p a n-e n k ' & \end{array}$

оставаться.AOR-2PL 1PL 2PL.ACC защищать.FUT/COND-1PL

'Поступайте, как хотите, но, если останетесь, мы защитим вac.' («Aravot», 2008.05.02)

В [Giorgi, Harutyunian 2011] к аористу со значением будущего относятся примеры типа (25) с проспективным значением или значением интенциональности ${ }^{26}$ и примеры типа (29), где событие, выраженное аористом, является гипотетической рамкой, которой обусловлена истинность события, выраженного в аподосисе.

В действительности, эти типы различает модальное и ассертивное измерение, которое является ключевым в примерах, рассматриваемых в данном разделе. В (25) событие представляется как достоверное, и, даже если временное значение не совпадает с речевой ситуацией, оно воспринимается говорящим как достоверное (ожидаемое). Напротив, в примерах типа (29) у аориста нет ассертивного значения; говорящий не делает утверждения об истинности пропозиции относительно ситуации дискурса (то есть событие не актуализировано), такая ситуация интерпретируется как гипотетическая, что в случаях со значением будущего создает рамку для другого утверждения, а в случаях с гномическим значением отсылает к общему знанию, не имеющему прямого отношения к ситуации дискурса.

${ }^{25}$ Употребления аориста, описываемые как имеющие значение будущего времени, встречаются только в ВА.

${ }^{26}$ Примеры, которые в [Lessan-Pezechki 1998] называются «аористом ожидания», встречаются также в современном греческом в $\eta$ ү $\theta \alpha$ 'пришел.AOR3SG' (буквально 'Я пришел!') при том, что говорящий (например, официант) еще не двигается к вам. 
При некоторых других значениях аориста, напротив, отсутствие временной отнесенности события к моменту речи не приводит к появлению проспективного значения. Это относится, в частности, к гномическому аористу ${ }^{27}$, как в приведенном ниже переводе Достоевского, где армянский аорист как во многих других примерах этого раздела соответствует русской форме будущего времени совершенного вида:

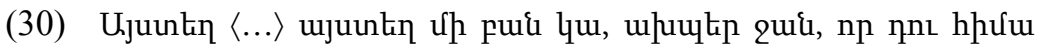

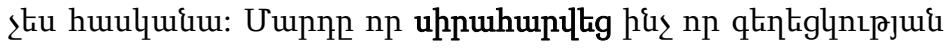

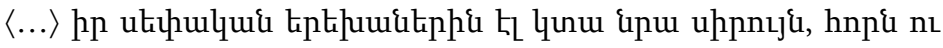
unpi h loupup $\langle\ldots\rangle$

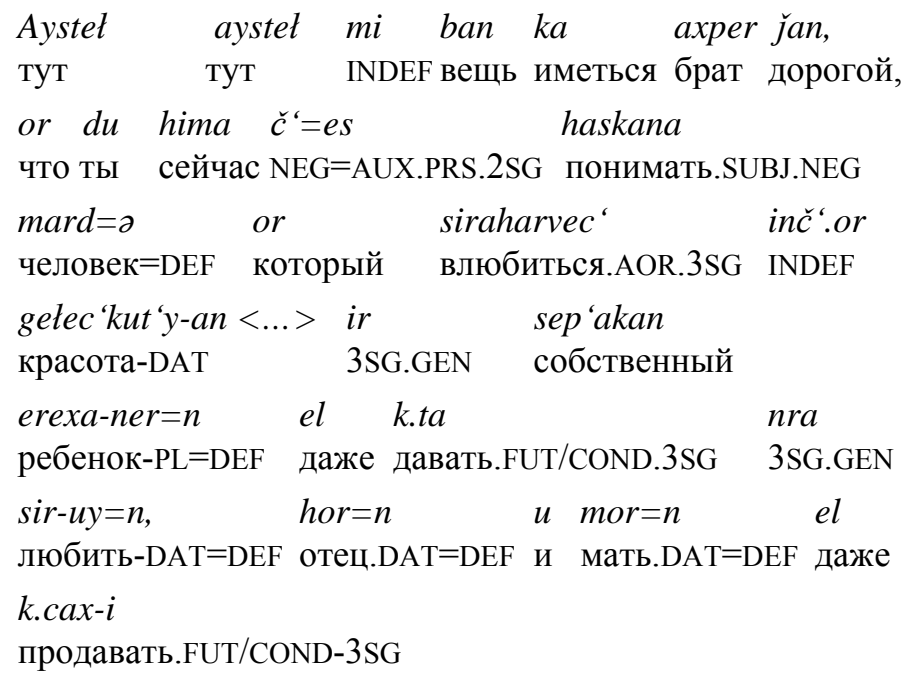

'Тут $\langle\ldots\rangle$ тут, брат, нечто, чего ты теперь не поймешь. Тут влюбится человек в какую-нибудь красоту, [в тело женское, или даже только в частью одну тела женского (это сладострастник может понять)], то и отдаст за нее собственных детей, продаст отца и мать, [будучи честен, пойдет и украдет; будучи кроток - зарежет, будучи верен изменит] 〈...〉' (Достоевский, «Братья Карамазовы»)

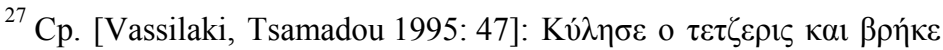

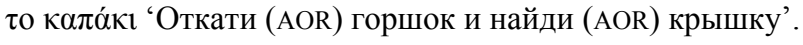


Это относится также к тому случаю, который в [LessanPezechki 1998] применительно к материалу персидского языка называется «модальный потенциальный аорист» ${ }^{28}$ :

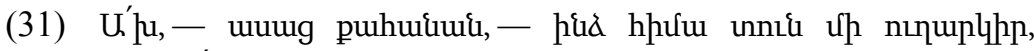

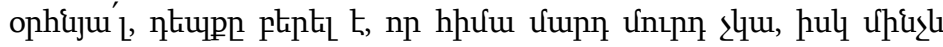

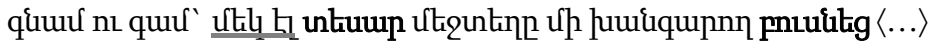

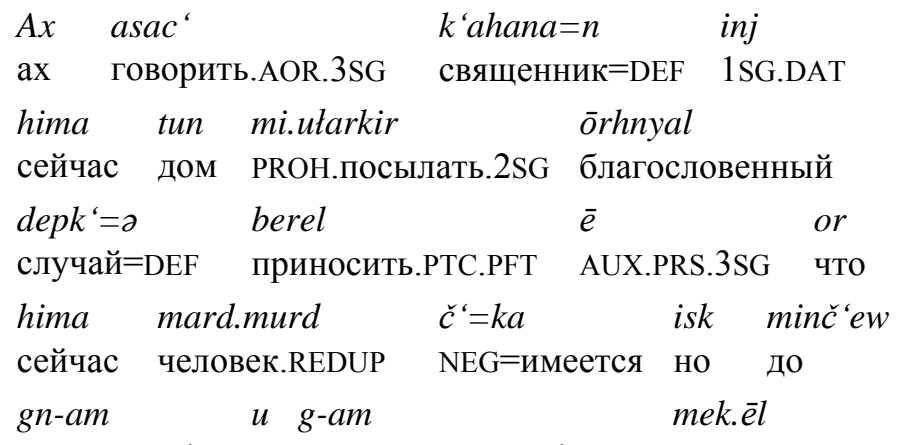

идти.SUBJ-1SG и приходить.SUBJ-1SG неожиданно

tes-ar mejteła mi xangarot busnec ‘

видеть.AOR-2SG среди INDEF помеха вырастать.AOR.3SG

'Ax, - сказал священник, - не отсылай меня теперь домой, потому, видишь ли, случай теперь такой подошел, что никого нет, а когда вернусь, того гляди - кто-нибудь подвернется, кто нам помешает 〈... (Джованни Боккаччо, «Декамерон»)

B [Vassilaki, Tsamadou 1995] отмечается, что гномический аорист и аорист “будущего” имеют общую характеристику: дизъюнкцию от $\mathrm{T}_{0}$. На наш взгляд, более предпочительно выделять здесь ассертивную характеристику, учитывая, что именно она определяет дизъюнкцию от $\mathrm{T}_{0}$, поскольку при отсутствии

${ }^{28}$ После причастий, означающих 'пожалуй' (перс. balke, šâิjad), он означает 'может, придет'. В армянском это значение появляется скорее после причастий или причастных словосочетаний, означающих внезапное осознавание, или даже после сериальных конструкций глаголов, содержающих глагол 'видеть', который токже выражает внезапность, ср. (30). 
подтверждения истинности пропозиции временное значение аориста остается непроявленным ${ }^{29}$.

Чтобы еще раз подчеркнуть, что так называемый парадокс, связанный с «футуральным» значением аориста, весьма относителен, отметим, что пример (30) допускает более одной интерпретации: «Если человек влюбится, он может продать отца и мать», «Если человек влюбится, он продаст отцуа и мать», «Как только человек влюбился, то он может продать отияа и мать» ${ }^{30}$. Иными словами, мы предполагаем, что специфичность подобных употреблений состоит не в их временном значении, а скорее в модальных и ассертивных свойствах аориста, которые могут нейтрализовать его временное значение с тем, чтобы акцентировать фазу возникновение события, факт изменения, что связано с видовым значением аориста, его событийностью и компактностью.

В сложных предложениях, содержащих протасис и аподосис (наиболее типичный случай) синтаксическая модель не является жесткой: допускаются вариации в союзе (et 'e 'если', or 'что', henc ' 'как только' и другие) или даже отстутствие союза в паратактических сложных предложениях, как в примере $(37)^{31}$. Аорист является обязательным в протасисе, но для аподосиса временные ограничения отсутствуют: допускаются такие времена как будущее/условное ${ }^{32}$ (29) и (37), будущее (32), оптатив (33), императив (34).

${ }^{29}$ В этом А. Джорджи и С. Арутюнян [Giorgi, Harutyunian 2011] безусловно правы, даже если нам кажется неправомочным распространять это на аорист в целом.

${ }^{30}$ См. также пример (35) наряду с (31), где значение аориста соответствует значению сложного будущего во французском (futur antérieur) и аналогичных значений аориста в персидском, отмеченных в [Lessan-Pezechki 1998]. В этой связи следует говорить не о противопоставленности значений аориста, относящихся к прошедшему и будущему, а о соположенности этих значений.

${ }^{31}$ В [Lessan-Pezechki 1998] для персидского у таких употреблений выделяется значение не будущего, а «гипотетического модального аориста», в придаточном с союзом agar 'если'.

${ }^{32}$ В некоторых случаях, это время, обозначаемое в грамматиках ВА как «условное», можно интерпретировать как показатель будущего. Значение будущего появляется в аподосисе условных предложений и в утверждениях, 


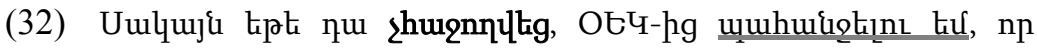

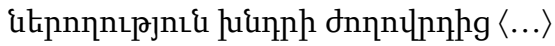

Sakayn et'e da $\check{c}^{\prime}=$ hajotvec $"$

OEK-ic ‘

но если это NEG=удаваться.AOR-3SG OEK-ABL

pahanjelu om or nerolut'yun

требовать.PTC.PROS AUX.PRS.1SG чтобы извинение

xndr-i žołovrd-ic ${ }^{\prime}$

посить.SUBJ-3SG народ-ABL

'Но если это не поможет, я потребую от «ОЕК», чтобы она извинилась перед народом’ («Aravot Daily», 2004.10.05)

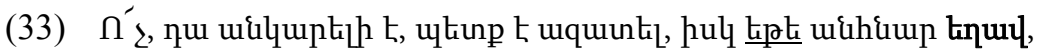
pnn utiap hL ulingliap apuigg htiun $\langle\ldots\rangle$

Oč da ankareli $\bar{e}$ petk

нет это невозможно COP.PRS.3SG необходимо

$\bar{e} \quad$ azatel isk et'e anhnar

COP.PRS.3SG освобождать а если невозможно

ełav t'ol menk' èl mern-enk'

COP.AOR.3SG пусть 1PL также умирать.SUBJ-1PL

nranc' het

3PL.GEN c

'Нет, это невозможно, они должны быть освобождены, а если это не удастся, пускай мы погибнем (оптатив) вместе с ними.' (Андраник Овсепян)

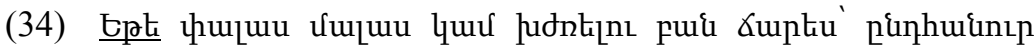

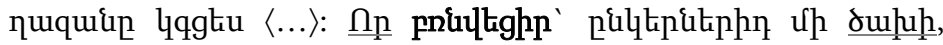

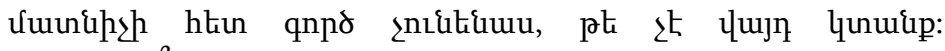
Zuulquigui $\mathrm{p}$ :

et'e p'alas.malas kam xžrel.u ban čar-es

если тряпка.REDUP или есть.DAT вещь найти.SUBJ-2SG

andhanur tazan-ə k.gc'-es or

общий котел-DEF класть.FUT/COND-2SG если

со значением близкого будущего или намерения (типа «не волнуйтесь, я приду»). По этой причине мы предпочитаем двойное глоссирование. 
binvec ${ }^{6}$-ir

$$
\text { onker-ner }=d \quad \text { mi.caxi }
$$

попасться.AOR-2SG друг-PL=2POSS PROH.продавать.2SG

$$
\text { matnič }-i \text { het gorc } \check{c} \text { ' }=\text { unen-as t'e.čce }
$$

стукач-GEN c дело NEG=иметь-SUBJ.2SG иначе

$$
\text { vay }=d \quad \text { k.tank' haskac '-ar }
$$

проклятие=2POSS давать.FUT/COND.1PL. понимать.AOR-2SG

'Если у тебя окажутся тряпки или еще что-нибудь, что ты стянул, клади все в общий котел. Если ты попался, не продавай товарищей. Не имей дел со стукачами, не то пожалеешь. Все понял?' (Варткес Тевекелян)

Времена, являющиеся типичными для актуализированных утверждений, такие как настоящее в примере $(35)^{33}$, придают аористу гномическое значение:

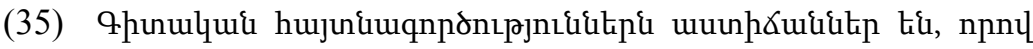

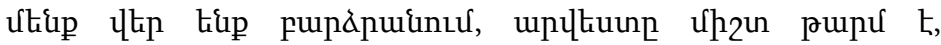

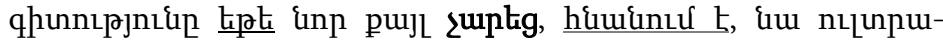
dưưquuluulhg uhhun hih:

Gitakan haytararut'yun-ner $=n$ astičan-ner en научное сообщение-PL=DEF ступень-PL AUX.PRS.3PL

or-ov menk'ver enk

который-INSTR 1PL наверx COP.PRS.1PL

barjranum arvest=o mišt t'arm

поднимать.PTC.PRS искусство=DEF всегда свежий

$\bar{e} \quad$ gitut'yun=o et'e nor k'ayl

COP.PRS.3SG наука=DEF если новый шаг

$\check{c} \check{c}^{\prime}=$ arec $^{\prime} \quad$ hnanum $\bar{e}$

$\mathrm{NEG}=$ делать.AOR.3SG стареть.PTC.PRS AUX.PRS.3SG

${ }^{33}$ Нам не удалось обнаружить примеры использования перфекта в аподосисе. Это объясняется тем, что значение условного наклонения меняется в перфекте. Оно могло бы обозначать, например, «Раз он отдал свою рубашку, значит, он ее сменил», то есть у аориста было бы значение прошедшего, ср. переход от 'если' к 'как только' в переводе примера (35). 
na ultražamanakakic‘ piti.lin-i

$3 \mathrm{SG}$ современный быть.DEB-3SG

'Научные сообщения - это ступени, по которым мы поднимаемся; искусство всегда сохраняет первозданную свежесть, наука же стареет, если не развивается (как только перестает развиваться), и всегда должна оставаться самой передовой.’ («Azg Daily», 2005.03.26)

Несмотря на отрицание, глагол здесь имеет ярко выраженное событийное значение, поскольку отсутствие «развития» интерпретируется как фатальная ошибка, которая имеет печальные последствия, что маркируется сочетанием et 'e 'если, как только' и дебитивом в следующей клаузе (ultražamanakakic ' piti lini).

Предложения с использованием аориста одновременно в протасисе и аподосисе также вполне возможны, особенно если высказывание звучит как угроза:

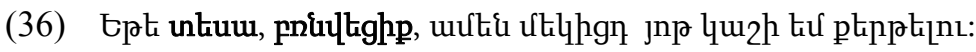

et'e tes-a binvec 'ik'

если видеть-AOR.1SG попадаться.AOR-2PL

amen.mek-ic ${ }^{\prime}=d \quad$ yot ${ }^{\prime} \quad$ kaši $\quad$ em

каждый-ABL=2POSS семь кожа AUX.PRS.1SG

$k^{\prime}$ ert'elu

отрывать.PTC.PROS

'Если только я вас увижу, вы попались, каждый из вас получит мучения.' (Сасун Варданян)

Как мы уже отмечали, эта синтаксическая структура с аористом в гипотетическом значении допускает разнообразные союзы или паратаксис:

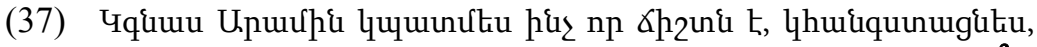

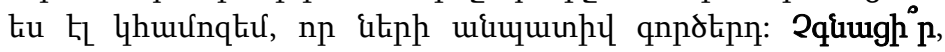
quupuitiu $\langle\ldots\rangle$.

k.gn-as aram- $i=n$

идти.FUT/COND-2SG Арам-DAT=DEF

k.patm-es inč'or č čšt $=n \quad \bar{e}$

рассказать.FUT/COND-2SG что правдивый=DEF COP 
k.hangstac'n-es es èl k.hamoz-em

успокоить.FUT.COND-2SG я также убедить.FUT/COND-1SG

or ner- $i \quad$ anpativ gorc-er- $i=d$

что простить.SUBJ-3SG недостойный работа-PL-DAT=2POSS

$\check{c}^{\varsigma}=$ gnac ${ }^{\boldsymbol{}}$-ir $\quad$ k.span-em

$\mathrm{NEG}=$ идти.AOR-2SG убить.FUT/COND-1SG

'Ты пойдешь к Араму ему расскажешь всю правду, ты его успокоишъ, а я попытаюсь уговорить его простить твое недостойное поведение. А если нет (не пойдешь), я тебя убью.' (Вахтанг Ананян)

Как видно из примера (31), также возможны сочетания, которые можно интерпретировать как сериальные конструкции. Здесь первый глагол утрачивает свою автономность и не может интерпретироваться как протасис. В сочетании с mēk el 'вдруг' он образует конструкцию, за которой часто следует аорист в гипотетическом значении.

3.2.3.2. Распределение аориста и субъюнктива в гипотетических конструкциях. Во всех примерах типа (29) и (32-35) аорист может быть заменен в протасисе субъюнктивом, при этом не затрагиваются ни грамматическое значение, ни общая семантика высказывания. Корпус содержит многочисленные примеры гипотетических предложений с субъюнктивом в аподосисе:

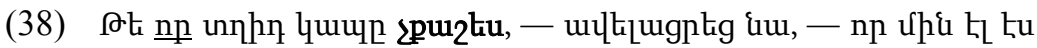

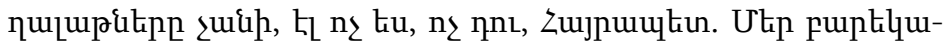

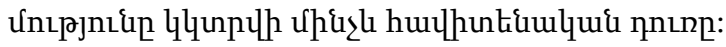
t'e. or $\quad t t-i=d$
$k a p=\partial$
если
сын-DAT $=2$ POSS
веревка $=\mathrm{DEF}$
$\check{c} ‘=k$ 'aš-es
avelac 'rec'
na or
$\mathrm{NEG}=$ прекратить.SUBJ-2SG добавлять.AOR.3SG $3 \mathrm{SG}$ что

$\min \bar{e} l \quad \bar{s} \quad$ talat'-ner $=$ ə

однажды также это способ-PL=DEF

$\check{c} \breve{c}=a n-i \quad \bar{e} l \quad o c ̌ c e s$

$\mathrm{NEG}=$ тянуть.SUBJ-3SG также не $1 \mathrm{SG}$

oč $d u$ hayrapet mer barekamut'yun=o

не 2SG, Айрапет 1PL.GEN дружба=DEF 
k.ktrv-i

minčew havitenakan dur $=0$

порваться.FUT/COND-3SG до вечный дверь=DEF

'Если ты не заставишь своего сына раз и навсегда прекратить все это, не станет ни тебя, ни меня, Айрапет. И наша дружба кончится навеки.' (Александр Ширванзаде)

Квазисинонимия между аористом и субъюнктивом в подобных конструкциях подтверждается примером из устного корпуса (39), где аорист и субъюнктив образуют последовательность действий:

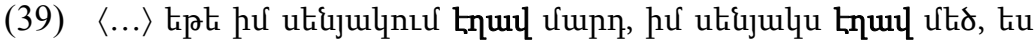

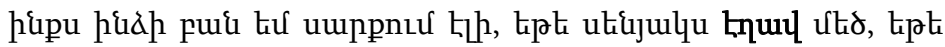

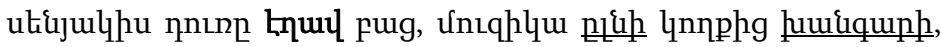

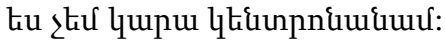

et'e im senyak-um èłav mard

если 1SG.GEN комната-LOC стать.AOR.3SG человек

im senyak $=s$ ètav mec

1SG.GEN комната=1POSS становиться.AOR.3SG большой es ink's inji ban em sark'um

1SG сам 1SG.DAT что-Tо AUX.PRS.1SG делать.PTC.PRS

èli et'e senyak=s èt-av mec

опять если комната-1POSS стать.AOR-3SG большой

et'e senyak $-i=s \quad d u \dot{r}=\partial \quad \bar{e} t a v$

если комната-GEN=1POSS дверь $=$ DEF стать.AOR.3SG

bac' muzika oln-i kotk'-ic'

открытый музыка стать.SUBJ-3SG сторона-ABL

xangar- $i$ es $\quad \check{c}=$ em kara

мешать-SUBJ3SG $1 \mathrm{SG}$ NEG=AUX.PRS.1SG мочь.SUBJ.NEG

kentronan-am

сосредотачиваться.SUBJ-1SG

'Если в моей комнате оказался кто-то, если моя комната оказалась (слишком) большая, я возмущаюсь, если моя комната оказалась большая, если дверь оказалась открыта, если звучит музыка и меня отвлекает, то я не могу сосредоточиться.' (OSD polylogue 128, 2006) 
Тем не менее, в отличие от субъюнктива, аорист акцентирует субъективный взгляд говорящего, передавая дополнительный оттенок внезапности в примере (34), предостережения и даже угрозы в примере (37), оттенок, который отличает предложения с 'если вдруг' от 'если' (последнее более свойственного предложениям с субъюнктивом в протасисе). В примере (34) гипотетическое предложение с аористом следует за первым гипотетическим предложением с субъюнктивом («Если у тебя окажутся тряпки или еще что-нибудь, что ты стянул, клади все в общий котел»), и аорист появляется именно в тот момент, когда звучит угроза («Если ты попался, не продавай товарищей <...> не то пожалеешь »). Это значение также соответствует выделенному выше значению «свершения», которое в русском переводе примера (39) передается добавлением глагола 'оказалась', то есть здесь предикация в армянском языке, хоть и выражена прилагательным, уже не является стативной предикацией качества, как было бы в настоящем времени. Употребление аориста подразумевает процесс типа достижения (по Вендлеру). Комната оказалась слишком большой, поскольку говорящий субъективно выделил этот ее признак.

Таким образом, этот тип употребления аориста подтверждает определенные выше инвариантные свойства аориста в дискурсе.

3.2.3.3. Параметры, которые определяют «футуральное» значение аориста. Специфическое значение предложений, в которых аорист принимает «футуральное» значение, не зависит от их синтаксической структуры; в корпусе можно обнаружить множество примеров, которые в синтаксическом плане тождественны предыдущим, но где у аориста проявляется значение прошедшего совершенного.

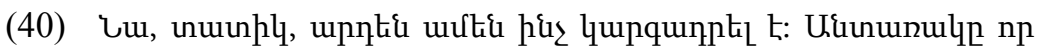

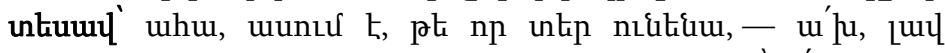

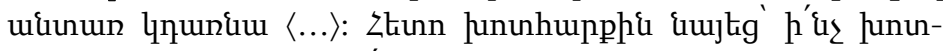

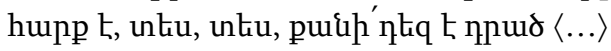

na tatik arden amen.inč kargadrel

3SG бабушка уже все распределить.PTC.PFT 
$\bar{e} \quad$ antarak=a or tes-av aha

AUX.PRS.3SG лесок=DEF который видеть.AOR-3SG вот asum $\bar{e}$ t'e or ter

говорить.PTC.PRS AUX.PRS.3SG что если хозяин

unen-a, akh lav antar k.darn-a

иметь.SUBJ-3SG ax хороший лес стать.FUT/COND-3SG

heto xothark' $-i=n \quad$ nayec

затем покос-DAT=DEF видеть.AOR.3SG

'- Он, бабушка, все уж распределил. Лесок увидал: вот, говорит, кабы на хозяина - ax, хорош бы был лесок! Потом на покосец посмотрел...' (Салтыков-Щедрин, «Господа Головлевы»)

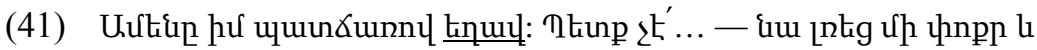

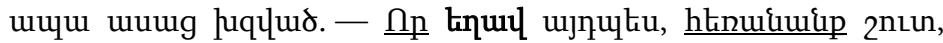

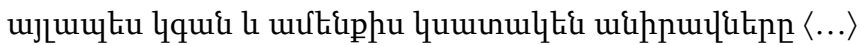

amena im patčarov ełav

все 1SG.GEN из-за стать.AOR.3SG

petk' $\check{c}^{\prime}=\bar{e}$ na líec ' mi.p'ok'r

нужно $\mathrm{NEG}=\mathrm{COP} . \mathrm{PRS} .3 \mathrm{SG} 3 \mathrm{SG}$ молчать.AOR.3SG немного

ew apa asac" xzvac or

и затем говорить.AOR.3SG отключенный что

etav aydpes heran-ank

быть.AOR.3SG так удаляться.SUBJ-1PL

šut aylapes k.g-an ew

быстро иначе приходить.FUT/CONG-3PL и

amenk' $-i=s \quad$ k.satak-en anirav-ner $=$ o

все-DAT=1POSS убивать.FUT/COND-3PL злодей-PL=DEF

'Все это случилось (aor.) из-за меня. Не нужно 〈...〉 Он помолчал немного, а потом сказал отрешенно: «Раз уж это произошло, быстро уйдем отсюда, а то придут злодеи и убьют всех нас.' (Стефан Зорьян)

Как мы видим, время глагола в аподосисе не является определяющим фактором, поскольку в гипотетических предложениях отмечены примеры с употреблением как настоящего времени (40), так и аориста (41). 
Не является здесь определяющей и сочинительная связь. Союз et'e 'если' имеет гипотетическое значение, но, как мы видели, может также обозначать «поскольку, потому что»предположение, что событие, действительно, актуализировалось как условие реализации содержания аподосиса. В результате аорист в протасисе имеет значение актуализированного события в прошлом. Напротив, союзы, которые происходят от временных маркеров, как henc' 'как только', имеющие отношение к прошедшему, могут употребляться с гипотетическим значением там, где аорист обозначениет неактуализированное событие.

Возникновению значения прошедшего времени у форм аориста в клаузах со значением будущего препятствует проспекивное значение предыдущего контекста, которое маркируется:

1) будущим временем или условным/будущим (в противоположность примерам (40) и (41), в которых эксплицитно выражена временная отнесенность к моменту в прошлом):

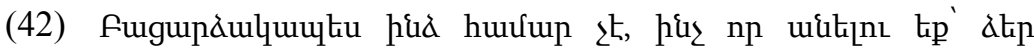

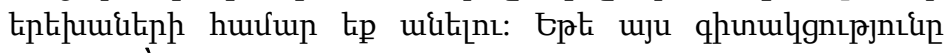

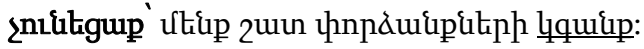

\begin{tabular}{|c|c|c|c|}
\hline bac'arjakapes & inj & hamar & inčs.or \\
\hline вовсе.нет & 1SG.DAT & для & $\mathrm{NEG}=\mathrm{COP} . \mathrm{PRS} .3 \mathrm{SG}$ что \\
\hline anelu & $e k^{6}$ & & erexa-ner-i \\
\hline
\end{tabular}

делать.PTC.PROS AUX.PRS.2PL 2PL.GEN ребенок-PL-DAT

hamar ek' anelu et'e ays

для AUX.PRS.2PL делать.PTC.PROS если этот

gitakc 'ut'yun=ə $\check{c}^{\prime}=$ unec $^{\prime}-a k^{\prime} \quad$ menk' ${ }^{\prime}$ at

знание $=\mathrm{DEF} \quad \mathrm{NEG}=$ иметь.AOR-2PL $1 \mathrm{PL}$ очень

p'orjank'-ner-i k.g-ank'

катастрофа-PL-DAT приходить.FUT/COND-1PL

'То, что вы намерены сделать, это уж точно не для меня, а для ваших же детей. А если вы этого не понимаете, то нас ждут большие катастрофы.' («Aravot Daily», 2008.05.29)

2) наречием со значением будущего:

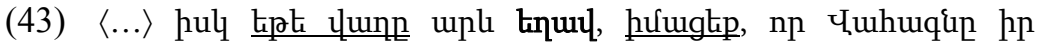

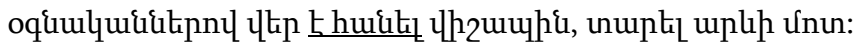




\begin{tabular}{llll} 
isk et'e vałə & arew & ełav & \multicolumn{2}{c}{ imac'-ek' } \\
и если завтра & солнце & быть.AOR.3SG & знать.AOR-2PL \\
or vahagn=ə & ir & ognakan-ner-ov & ver \\
что Ваган=DEF & 3SG.GEN & помощник-PL-INSTR & вверх
\end{tabular}

$\bar{e} \quad$ hanel višap $-i=n$

AUX.PRS.3SG поднять.PFT дракон-DAT=DEF

tarel arew-i mot

унести.РТС.PFT солнце-DAT к

'И если завтра встанет солнце, знайте, что Ваган оседлал дракона и направил его к солнцу.' (Карен Мусаелян)

3) или же любым другим элементом с проспективным значением в предшествующем контексте, таким как глагол в императиве (31) или даже глагол со значением 'надеяться' (44):

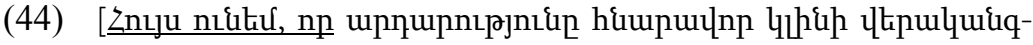

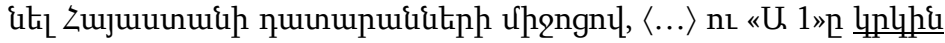

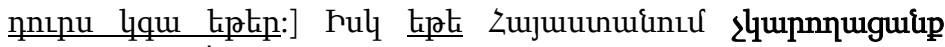

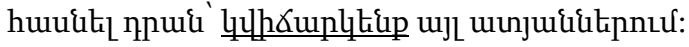

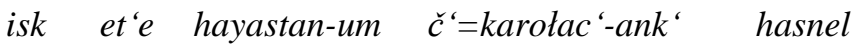
и если Армения-LOC NEG=мочь.AOR-1PL достичь dran k.vičark-enk' ayl atyan-ner-um тот.DAT бороться.FUT/COND-1PL другой суд-PL-LOC

‘[Я надеюсь, что с помощью судов Армении удастся восстановить справедливость и А1 вернется в эфир.] А если в Армении этого не добьемся, мы будем обращаться в другие суды.' («Aravot Daily», 2002.05.22)

3.2.3.4. Предварительные выводы: модальная и ассертивная природа «футуральных» употреблений аориста. Как было показано, так называемое значение будущего у аориста, в действительности, представляет собой скорее модальное значение (гипотетическое или потенциальное). В этом смысле нам кажутся удачными термины, предложенные в [Lessan-Pezechki 1998]. Именно временной или модальный контекст препятствует реализации значения прошедшего у аориста, сохраняя лишь видовое значение компактного события при значении неактуализованной ассертивности. Как было показано выше, аористу в его 
так называемых «футуральных» употреблениях присущи все аспектуальные свойства, которые мы выделили для других употреблений аориста (компактное событие, предъявленное как достижение, с модальным значением неожиданности, которое может реализовываться в дискурсивном регистре).

По этой причине, представляется неправомочным утверждение о том, что значение будущего времени является одним из значений аориста. Эти значения являются контекстно обусловленными в некоторых гипотетических предложениях, где инвариантное значение аориста, дизъюнкция по отношению к $\mathrm{T}_{0}$, обусловливает его видовое значение, и оставляет невыраженным его временное значение. Такой подход позволяет нам рассматривать вместе гномическое и гипотетическое значения аориста, поскольку в обоих случаях ситуация высказывания отступает на второй план и координаты высказывания $\left(\mathrm{S}_{0}, \mathrm{~T}_{0}\right)$ остаются не задействованными.

Различие между гномическим и гипотетическим значениями связано с локализацией относительно речевой ситуации. При гипотетических употреблениях, протасис не актуализирован, и, таким образом, имеет место дизъюнкция от $\mathrm{T}_{0}$, между тем как другие координаты высказывания (прежде всего, $\mathrm{S}_{1}$ ) активированы, что позволяет проявляться таким субъективным значениям как «неожиданность» или «угроза». Напротив, гномический аорист предполагает отсутствие активации всех координат высказывания: исключаются 1 и 2 лицо, истиннность содержания не касается конкретной ситуации, отсутствует связь с $\mathrm{S}_{0}$ и, соответственно, не могут проявляться такие субъективные значения, как «удивление» или «неожиданность».

В обоих случаях, событие в аористе не является ассертивным в том смысле, в каком ассертивность определена в конце раздела 1. В протасисе она образует рамку, от коротой зависит актуализация аподосиса. Протасис может либо 1) выражать гипотезу, которая может подтвердиться в будущем (гипотетически), что приведет к актуализации аподосиса, либо 2) выражать событие, от которого зависит истинность аподосиса. Иными словами, в этих предложениях актуализируется корреляция между протасисом и аподосисом. 
Такие употребления аориста, в отличие от остальных рассмотренных выше типов, ограничено ВА и не встречается в ЗА, где подобные высказывания реализуются не в аористе, а в субъюнктиве.

\section{4. Общее выводы: инвариантные и контекстые значения аориста в армянском языке}

В данной статье мы попытались показать, что аорист в армянском языке можно определить тремя инвариантными свойствами, из которых выводятся все его засвидетельствованные значения, представляющие собой результат взаимодействия этих свойств с теми или иными контекстными параметрами высказываний. Эти генерализованные свойства позволяют учесть всё разнообразие значений и учесть упоминающиеся в грамматиках ограничения на употребление аориста, не прибегая к перечислению большого числа частных правил и исключений. Кроме того, как было показано в разделе 1, эти инвариантные свойства коррелируют с морфологическими свойствами аориста в армянском.

\section{1. Ассертивные типы высказывания}

Эти три свойства, событийность, компактность и отсутствие локализации относительно $\mathrm{T}_{0}$, проявляются по-разному в зависимости от ассертивного типа предложения. Мы выделили три типа: нарративный и дискурсивный регистры в простых ассертивных предложениях, а также протасис в гипотетических сложных предложениях.

В нарративном регистре темпоральная локализация события определяется дизъюнкцией от $\mathrm{T}_{0}$, что хорошо согласуется с инвариантными значениями аориста: событие рассматривается независимо от ситуации высказывания, темпоральная локализация определяется через контекст и выражается с помощью обстоятельственных маркеров и/или за счет хронологической последовательности событий. Аорист описывает событие в прошлом и не имеет дополнительного модального значения.

В дискурсивном регистре, который предполагает речевую ситуацию, локализация выражается не аористом как таковым; ассертивность актуализируется за счет ситуации высказывания. За счет несовпадения темпоральной локализации аориста (что 
выражено и в его морфологических особенностях) с локализацией дискурсивного регистра возникают модальные значения, различные для глаголов с различной семантикой (внутреннее состояние; достижение, возникшее в результате спонтанного процесса, и т.д.). Общими признаками этих модальных значений являются следующие:

1) В отношении аспектуальных характеристик, это признак свершения (связанный со свойством компактности и проявляющийся в фазовых значениях инхоатива, изменения состояния, достижения или моментальности в случае антиципации).

2) В отношении модальных характеристик, это признак сильного утверждения (например, в контекстах восклицания, спора, неожиданного осознания или подчеркнутой значимости чего-либо). Этот признак может быть соотнесен с некоторыми миративными значениями.

В гипотетических дискурсивных предложениях аорист появляется чаще всего в протасисе, который является ассертивным не в полной мере (утверждение не содержит информации об истинности пропозиции), и событие описывается как гипотетическая рамка, которая может актуализировать событие в аподосисе. В семантическом плане такие предложения могут быть двух типов:

1) Проспективная гипотеза о наступлении события («если когда-либо») с разнообразными субъективными коннотациями (отрицательные последствия, миративность, угроза и.т.д.), при которой учитывается, что в данной ситуации событие может возникнуть или не возникнуть в будущем.

2) Общая гипотеза, охватывающая целый класс событий, при которой утверждается гномическая истина, определяющая истинность любого события данного класса.

\section{2. Инварианты, определяющие аорист}

В трех указанных регистрах инвариантные значения аориста проявляются определенным образом в зависимости от свойственных для этих регистров параметров высказывания. При этом в каждом случае аорист противопоставлен двум другим временам.

4.2.1. Темпоральная локализащия. Аорист является прошедшим временем, характеризующимся дизьюнкцией от $\mathrm{T}_{0}$. В этом 
отношении он противопоставлен: а) перфекту, с которым он разделяет признак «прошедшее завершенное», и б) субъюнктиву, что согласуется с морфологическими особенностями, приведенными в Таблице 2.

Аорист ориентирован на событие, в то время как перфект ориентирован на актуальность ситуации относительно момента высказывания. Таким образом, аорист является временем нарратива, тогда как пефект предполагает ситуацию высказывания ${ }^{34}$.

В дискурсивных контекстах, ориентированность на событие создает эмфатическую ассертивность, подчеркивающую значение наступления события; при этом может появляться ряд коннотаций: сильное утверждение (19), аргумент (20-21) и, наконец, экскламация (22-23).

В контекстах, где актуализации события не происходит (гипотеза), и нет темпоальной локализации, аорист может быть употреблен без временного значения как аналог субъюнктива. В противоположность последнему, видовое значение аориста сохраняется, и предложение получает значение наступления события с различными субъективными коннотациями (отрицательные последствия, угроза, неожиданность и.т.д.); в контекстах, выражающих сильную угрозу, аористом может быть выражен также аподосис, как в примере (36).

4.2.2. Свойства компактности/целостности и динамичности/событийности. Аорист предполагает предельность и в этом он противопоставлен результативному перфекту, который переводит предикат из акционального класса событий в класс состояний. Именно это свойство аориста обеспечивает локализацию последовательных событий относительно друг друга в нарративном контексте. Компактность не позволяет дробить событие на отдельные фазы, представляя каждое событие как отдельную фазу, что соответствует пониманию события как предиката достижения в понимании Вендлера (пример (7)). Таким образом, аорист может влиять на лексическую семантику глагола, обеспечивая возможный переход глагола из одного

${ }^{34}$ Использование пефекта в нарративе создает референтную ситуацию, как показано в примере в сноске 19. 
акционального класса в другой: дуративные непредельные глаголы или даже стативные и бытийные глаголы (6), (39) могут быть представлены, благодаря аористу, как недлительные предельные события, приобретая либо дополнительные аспектуальные значения (такие как инхоатив (21-24), значение антиципации (25), либо дополнительные модальные значения (такие как значение телеологической модальности (26-27) и значение подчеркнутой значимости номинируемого события с акцентом на интенциональности совершения действия (28).

4.3. Морфологические свойства аориста в глагольной системе современного армянского языка

В статье было показано, каким образом каждое из рассмотренных частных значений аориста может быть объяснено через сочетание инвариантных значений и особенностей различных типов локализаторов. При этом инвариантные значения соотносятся с морфологическими признаками аориста:

1) Перфективность (проявляется в основе и объединяет аорист с разновидностями перфекта);

2) Прошедшее время (проявляется во флексии и объединяет аорист со всеми глагольными временами, входящими в коррелятивные пары, выражающие темпоральную оппозицию между прошедшим и настоящим, см. Таблицу 1);

3) Отсутствие эксплицитного маркирования актуализации действия (см. Таблицу 3) (общий признак с субъюнктивом);

4) Отсутствие коррелятивной пары в рамках бинарной оппозиции прошедшего и настоящего времени (общий признак с императивом).

Совокупность этих морфологических признаков согласуются с рассмотренными семантическими свойствами аориста.

\section{4. Кросс-лингвистические константы и особенности}

Как было показано, инвариантные значения армянского аориста, которые соотносятся с константами «аористичности», выделенными Кюльоли, соответствуют описаниям аориста в ряде индоевропейских языков. Очевидно, что многие черты аориста в этих языках не совпадают, даже в ВА и 3А; в последнем аорист не употребляется с так называемым футуральным значением в 
протасисе гипотетических конструкций. Для этого можно предложить ряд объяснений, не исключающих друг друга, например:

1) Некоторые употребления относятся скорее к словосочетаниям (как, например, сериальная конструкция в (31)) или же устойчивое клише с kspanem 'Я убью (тебя)' в (37), очень частотная в разговорном ВА. Несмотря на то, что употребление аориста в гипотетических предложениях не характерно для 3А, его значение остается вполне прозрачным для носителей $3 \mathrm{~A}^{35}$. На различия в употреблении аориста могли повлиять ареальные особенности: в турецком языке, в контакте с которым развивался ЗА, гипотетический аорист отсутствует, в то время как в иранском ареале, где развивался ВА, подобные употребления аориста прослеживаются.

2) Структура глагольной системы любого языка и, в частности, системы его временных категорий определяется характерными для нее различительными признаками. Что касается различий между 3А и ВА, а также некоторыми другими рассмотренными выше языками, наличие или отсутствие специальных времен с миративным или эвиденциальным значениями оказывает существенное влияние на модальные значения аориста. Так, например, в современном греческом языке отсутствие эвиденциального или миративного времени объясняет рассмотренные в (22-23) значения аориста. Аналогичным образом в глагольной системе хинди миративные значения выражаются аористом. Напротив, в современном ЗА, где выделяется специальное время со значением эвиденциальности, модальные значения аориста существенно более ограниченны по сравнению с современным BA, поскольку значения сильного утверждения, подчеркнутой значимости события, аргумента или восклицания выражаются в современном 3А эвиденциальным временем (см. [Bonnot, Donabédian 1999; Donabédian 1996, 2001, 2012]).

Таким образом, для выявления специфических черт аориста в том или ином языке следует учитывать формальные свойства и существующие в глагольной системе оппозиции между временны-

${ }^{35}$ В частности, аорист встречается в ЗА в афоризмах, хотя здесь прослеживается тенденция к его вытеснению эвиденциальной формой. 
ми формами. Выявленные в данной статье базовые характеристики аориста предполагают, что его временные, аспектуальные и модальные значения зависят от перечисленных выше параметров высказывания, контекста, и, что особенно важно, - от места аориста в системе временных оппозиций в отдельно взятом языке.

\section{Список условных сокращений}

$=$ - показатель клитики; 1, 2, 3 - лицо у глагола, местоимений и притяжательных частиц; $\mathrm{ABL}$ - аблатив; AOR аорист; AUX - вспомогательный глагол; COP — копула; DAT датив; DEB - дебитив; DEF - показатель определенности; EVID - эвиденциальность; FUT/CONJ - будущее время/конъюнктив; GEN - генитив; INDEF - показатель неопределенности; INSTR - инструменталис; IPF - имперфект; LOC - локатив; NEG - показатель отрицания; PFT - перфект; PL — множественное число; POSS - притяжательность; PROH - запретительное наклонение; PROS - проспектив; PRS - настоящее время; PST прошлое; PTC - причастие; REDUP - удвоение; SG - единственное число; SUBJ - субъюнктив.

\section{Литература}

Маслов 1981 - Ю. С. Маслов. Грамматика болгарского языка. М.: Высшая Школа, 1981. [Iu. S. Maslov. Grammatika bolgarskogo iazyka [Grammar of the Bulgarian language]. Moscow: Vysshaia shkola, 1981].

Плунгян 2006 - В. А. Плунгян. К описанию армянской глагольной парадигмы: «темпоральная подвижность» и перфектив // Армянский гуманитарный вестник 1, 2006. C. 7-20. [V. A. Plungian. K opisaniiu armianskoi glagol'noi paradigmy: «temporal'naia podvizhnost'» i perfektiv // [Contribution to the description of the Armenian verbal paradigm: "temporal mobility" and the perfective] // Armianskii gumanitarnyi vestnik 1, 2006. P. 7-20].

Abeghyan 1965 - M. Abeghyan. Hayoc' lezvi tesut'yun. Erevan: Mitk‘, 1965.

Barchian 2003 - A. Barchian. Doit-on considérer la différence entre le passé simple et passé composé comme une différence aspectuelle?// A. Donabédian, A. Ouzounian (eds.). Actes du Sixième Colloque international de Linguistique arménienne: INALCO, Académie des 
inscriptions et belles-lettres, 5-9 juillet 1999 (Slovo 26-27, 2001-2002), Paris: INALCO, 2003. P. 299-309.

Bonnot, Donabédian 1999 - C. Bonnot, A. Donabédian. Lorsque la morphosyntaxe rencontre la prosodie: accent non final en russe et médiatif en arménien // Faits de Langues 10, 1999. P. 182-190.

Cohen 1985 - D. Cohen. L'aspect verbal. Paris: PUF, 1985.

Culioli 1980 - A. Culioli. Valeurs aspectuelles et opérations énonciatives: l'aoristique // J. David, R. Martin (eds.). La notion d'aspect. Vincennes: Recherches linguistiques, 1980. P. 182-193.

Culioli 1990 - A. Culioli. Pour une linguistique de l'énonciation. Paris: Ophrys, 1990.

Dahl 1985 - Ö. Dahl. Tense and Aspect Systems. Oxford: Blackwell, 1985. Donabédian 1996 - A. Donabédian. Pour une interprétation des différentes valeurs du médiatif en arménien occidental // Z. Guentchéva (éd.). L'énonciation Médiatisée. Louvain: Peeters, 1996. P. 87-108.

Donabédian 2001 - A. Donabédian. Toward a Semasiological account of Evidentials: an Enunciative Approach of $-e r$ in Modern Western Armenian // Journal of Pragmatics 33/3, 2001. P. 421-442.

Donabédian 2012 - A. Donabédian. Evidentiel et progressif: quel statut grammatical pour la saillance prédictive ?// Faits de Langues 39, 2012. P. 65-82.

Donabédian 2016 - A. Donabédian. The Aorist in Modern Armenian: core value and contextual meanings // Z. Guentchéva (ed.). Aspectuality and Temporality. Descriptive and theoretical issues. Amsterdam Philadelphia: John Benjamins, 2016. P. 375-411.

Dum-Tragut 2009 - J. Dum-Tragut. Armenian (Modern Eastern Armenian). Amsterdam - Philadelphia: John-Benjamins, 2009.

Giorgi, Harutyunian 2011 - A. Giorgi, S. Harutyunian. Remarks on Temporal Anchoring: The case of the Armenian aorist // Working Papers in Linguistics 21, 2011. P. 83-105.

Guentchéva 1990 - Z. Guéntcheva. Temps et aspect, l'exemple du bulgare contemporain. Paris: CNRS Editions, 1990.

Lazard 1957 - G. Lazard. Grammaire du persan contemporain. Paris: Klincksiek, 1957.

Lessan-Pezechki 1998 - H. Lessan-Pezechki. L'aoriste persan // M. Maillard (éd.). La conception métagrammienne du temps verbal (Le langage et l'Homme 33, 2-3), Louvain: Peeters, 1998. P. 195-202.

Lessan-Pezechki 2002 - H. Lessan-Pezechki. Système verbal et Deixis en persan et en français. Paris: L'Harmattan, 2002.

Markarian 2004 - A. Markarian. Hayoc' lezvi k'erakanut'yun. Jewabanu$t^{\prime}$ yun. Yerevan State University Press, 2004. 
Montaut 2006a - A. Montaut. Mirative Meanings as Extensions of Aorist in Hindi/Urdu // R. Singh (ed.). The Yearbook of South Asian Languages and linguistics. Thousand Oaks: Sage, 2006. P. 49-70.

Montaut 2006b - A. Montaut. Figures du sujet énonciateur: deux cas particuliers du discontinu et du continu en hindi/ourdou // D. Ducard, C. Normand (éds.). Actes du colloque de Cerisy "Antoine Culioli, un homme dans le langage". Paris: Ophrys, 2006. P. 187-208.

Robert 1996 - S. Robert. Aspect zéro et dépendance situationnelle: l'exemple du wolof // C. Müller (éd.), Dépendance et intégration syntaxique (subordination, coordination, connexion) (Linguistische Arbeiten 351). Tübingen: Niemeyer, 1996. P. 153-161.

Sauvageot 1965 - S. Sauvageot. Description synchronique d'un dialecte wolof: le parler du Dyolof. Dakar: IFAN, 1965.

Vassilaki, Tsamadou-Jacoberger 1995 - S. Vassilaki, I. TsamadouJacoberger, Irène. Aspects du grec moderne. Lallies 15. Paris: Presses de l'ENS, 1995. P. 7-69.

Vogüé 1989 - S. de Vogüé. Littérature et linguistique : la catégorie de l'histoire // Semen 4, 1989. (http://semen.revues.org/6713).

Vogüé 1995 - S. de Vogüé. L’Effet aoristique // J. Bouscaren, J. J. Frankel, S. Robert (éds.). Langues et langages. Problèmes et raisonnement en linguistique. Paris: PUF, 1995. P. 247-259. 